\title{
Evaluation of Dredged Material Proposed for Ocean Disposal from MOTBY
}

\author{
E. S. Barrows \\ H. L. Mayhew \\ J. Q. Word
}

Battelle Marine Sciences Laboratory

Sequim, Washington

September 1996

Prepared for the U.S. Army Corps of Engineers - New York District under a Related Services Agreement with the U.S. Department of Energy under Contract DE-AC06-76RLO 1830

Pacific Northwest National Laboratory Operated for the U.S. Department of Energy by Battelle Memorial Institute 


\title{
DISCLAIMER
}

This report was prepared as an account of work sponsored by an agency of the United States Government. Neither the United States Government nor any agency thereof, nor Battelle Memorial Institute, nor any of their employees, makes any warranty, express or implied, or assumes any legal liability or responsibility for the accuracy, completeness, or usefulness of any information, apparatus, product, or process disclosed, or represents that its use would not infringe privately owned rights. Reference herein to any specific commercial product, process, or service by trade name, trademark, manufacturer, or otherwise does not necessarily constitute or imply its endorsement, recommendation, or favoring by the United States Government or any agency thereof, or Battelle Memorial Institute. The views and opinions of authors expressed herein do not necessarily state or reflect those of the United States Government or any agency thereof.

\author{
PACIFIC NORTHWEST NATIONAL LABORATORY \\ operated by \\ BATTELLE MEMORIAL INSTITUTE \\ for the \\ UNITED STATES DEPARTMENT OF ENERGY \\ under Contract DE-AC06-76RLO 1830
}

Printed in the United States of America

Available to DOE and DOE contractors from the Office of Scientific and Technical Information, P.O. Box 62, Oak Ridge, TN 37831; prices available from (615) 576-8401.

Available to the public from the National Technical Information Service, U.S. Department of Commerce, 5285 Port Royal Rd., Springfield, VA 22161 


\section{DISCLAMMER}

Portions of this document may be illegible in electronic image products. Images are produced from the best available original document. 


\title{
EVALUATION OF DREDGED MATERIAL
} PROPOSED FOR OCEAN DISPOSAL

\section{FROM MOTBY}

\author{
E. S. Barrows \\ H. L. Mayhew \\ J. Q. Word
}

Battelle Marine Sciences Laboratory

Sequim, Washington

September 1996

Prepared for the

U.S. Army Corps of Engineers - New York District under a Related Services Agreement

with the U.S. Department of Energy

under Contract DE-AC06-76RLO 1830

Pacific Northwest National Laboratory

Richland, Washington 99352 


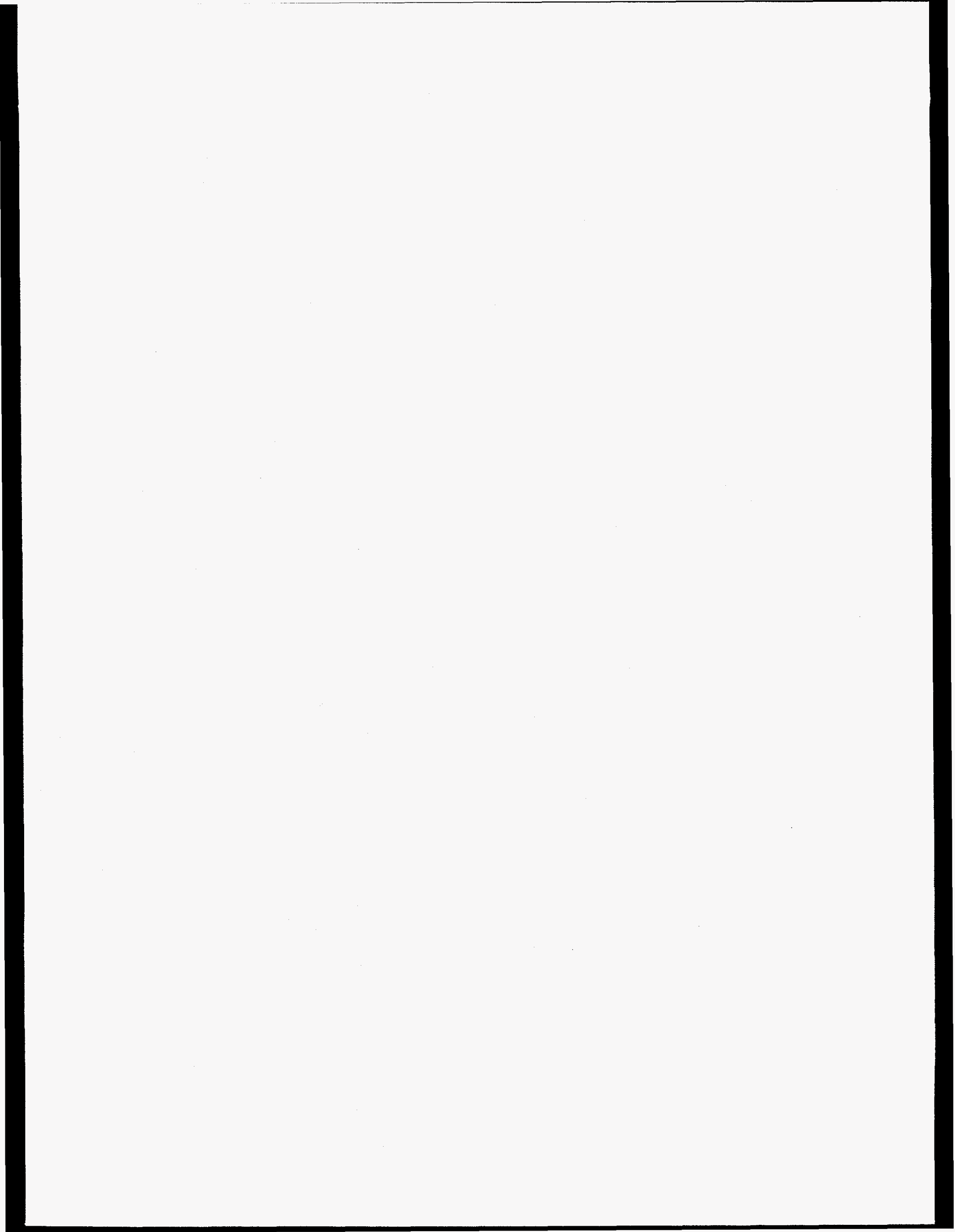




\section{Summary}

The National Park Service, U. S. Department of the Interior requested U.S. Army Corps of Engineers/New York District (USACE-NYD) to evaluate sediments around the Military Ocean Terminal (MOTBY) in Bayonne, New Jersey. Sediment samples were collected from MOTBY, during a survey conducted from June 7 through June 10, 1994.

Tests and analyses were conducted on MOTBY sediment core samples according to the manual developed by the USACE and the U.S. Environmental Protection Agency (EPA), Evaluation of Dredged Material Proposed for Ocean Disposal (Testing Manual), commonly referred to as the "Green Book," and the regional manual developed by the USACE-NYD and EPA Region II, Guidance for Performing Tests on Dredged Material to be Disposed of in Ocean Waters. The evaluation of proposed dredged material from MOTBY included grain size and total organic carbon (TOC) analyses and one acute toxicity test with the amphipod Ampelisca abdita. Individual sediment core samples collected from MOTBY were analyzed for grain size and TOC: The amphipod benthic toxicity test procedures followed EPA guidance for reduction of total ammonia concentrations in test systems prior to test initiation. In addition to the benthic toxicity test, a bioaccumulation test (28-day exposure) was conducted with the deposit-feeding clam Macoma nasuta, and the suspension-feeding clam Tapes japonica. Clam tissue samples were not analyzed as part of this project, but were archived frozen for possible future analyses of contaminants of concern.

MOTBY sediment core samples were predominantly black, silty-clayey material. Percentages of silt ranged from $13 \%$ to $79 \%$, and of clay, from $11 \%$ to $46 \%$. Sediment moisture contents varied from $10 \%$ to $64 \%$ in individual cores. TOC measurements for MOTBY sediments ranged from $1.6 \%$ to $5.0 \%$.

Survival of $A$. abdita in the MT-A and MT-B composites were $86 \%$ and $71 \%$, respectively, and only MT-B was significantly lower than that of the Mud Dump Reference Site sediment ( $94 \%$ survival). Therefore, MT-B sediment did not meet the limiting permissible concentration (LPC) for benthic toxicity to $A$. abdita, if the observed effects are due to persistent contaminants. 


\section{Contents}

Summary

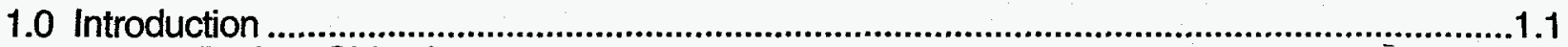

1.1 Project Objectives ...............................................................................................1.1

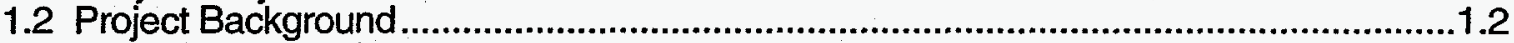

1.3 Organization of this Report .................................................................................1.2

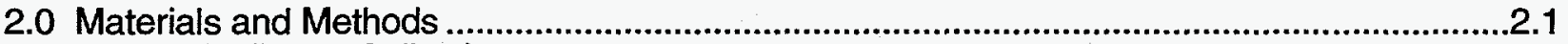

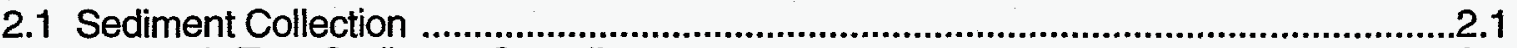

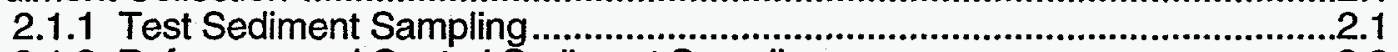

2.1.2 Reference and Control Sediment Sampling ...............................................2.2

2.2 Test Organism Collection ........................................................................................2.2

2.3 Sediment Sample Preparation ..............................................................................

2.3.1 Laboratory Preparation and Safety Considerations........................................

2.3.2 Preparation of Sediment for Benthic Testing and Bulk Sediment Analyses ................................................................2.4

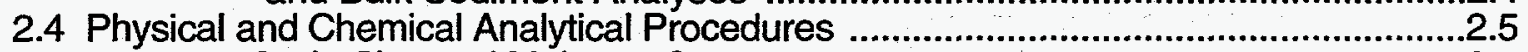

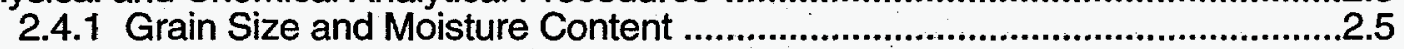

2.4 .2 TOC ...

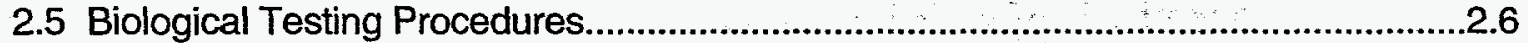

2.5.1 Benthic Acute Toxicity Test with Ampelisca abdita .....................................

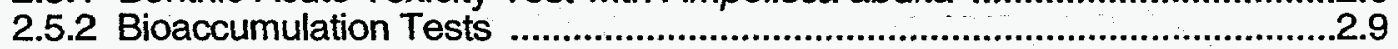

2.6 Data Analysis and Interpretation Procedures.........................................................2.10

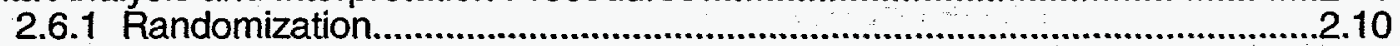

2.6.2 Statistical Analysis of the Benthic Toxicity Test .........................................2.10

2.7 Quality Assurance/Quality Control Procedures ..........................................................2.10

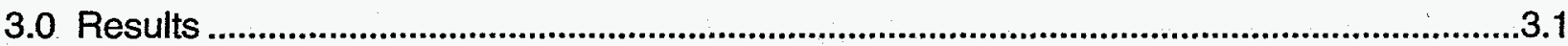

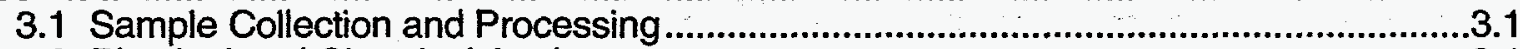

3.2 Physical and Chemical Analyses ............................................................................

3.2.1 Sediment Core Sample Description ……….....................................................

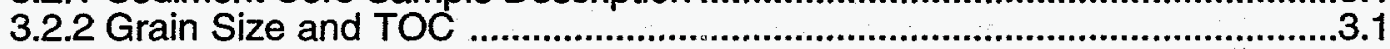

3.3 Benthic Acute Toxicity Testing ................................................................................

3.4 Bioaccumulation Testing ....................................................................................................

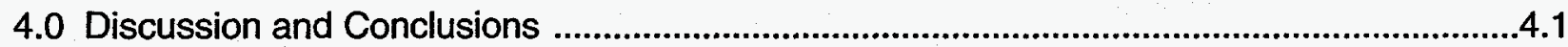

4.1 Sediment Physical and Chemical Characterization ........................................................1

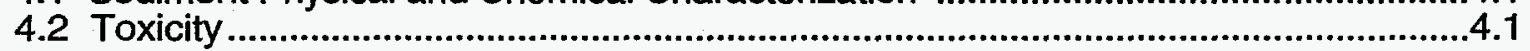

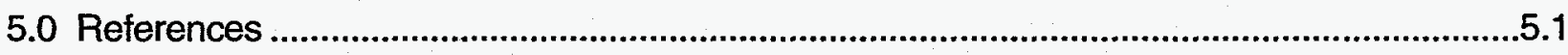

Appendix A. Quality Assurance/Quality Control Data for Sediment Grain Size and TOC Analyses, MOTBY.......................................................................... A.1

Appendix B. Benthic Acute Toxicity Test Data, MOTBY …................................................. B.1

Appendix C. Bioaccumulation Test Data, MOTBY ….......................................................... 


\section{Figures}

FIGURE 1.1 Location of MOTBY Project Area and Sample Collection Stations ......................1.3

FIGURE 2.1 Testing Containers for Amphipod Static Renewal Toxicity Tests .......................2.7

\section{Tables}

TABLE 2.1 List of Analytes, Methods, and Target Detection Limits .....................................2.6

TABLE 3.1 Summary of Sediment Sample Data for MOTBY ................................................2

TABLE 3.2 MOTBY Sediment Core Descriptions..............................................................3.3

TABLE 3.3 Results of Analysis of MOTBY Sediment Samples for Grain Size, Moisture Content, and TOC

TABLE 3.4 Summary of Benthic Acute Toxicity Test Performed with MOTBY Sediment. 


\subsection{Introduction}

\subsection{Project Objectives}

The objective of the Military Ocean Terminal Bayonne (MOTBY) project was to evaluate proposed dredged material from MOTBY located in the Upper Bay of New York Harbor to determine its suitability for unconfined ocean disposal at the Mud Dump Site. The Mud Dump Site is the present dredged material disposal site for the Ports of New York and New Jersey. It lies in the apex of the New York Bight about 6 miles east of Sandy Hook, New Jersey, and 12 miles south of Rockaway Point, New York.

A reference sediment from the Mud Dump Reference Site was also collected and compared with the MOTBY sediments to evaluate potential impacts of disposal of these sediments. The Mud Dump Reference sediment is located approximately 2.6 miles southwest of the center of the Mud Dump Site.

Chemical analyses were conducted on 12 MOTBY sediment core samples and 2 MOTBY sediment composites sediment composites, and biological testing was performed on the 2 sediment composites (COMP MT-A and MT-B). COMP MT-A is a homogenous mixture of stations MT-A-1 through MT-A-6 and COMP MT-B is a homogenous mixture of stations MT-B-7 through MT-B-12. The chemical and biological analyses were conducted according to the manual developed by the U.S. Army Corps of Engineers (USACE) and the U.S. Environmental Protection Agency (EPA), Evaluation of Dredged Material Proposed for Ocean Disposal (Testing Manual) (EPAUSACE 1991), commonly referred to as the "Green Book," and the regional manual developed by the USACE-New York District (NYD) and EPA Region II, Guidance for Performing Tests on Dredged Material to be Disposed of in Ocean Waters (USACE-NYD/EPA Region II 1992), hereinafter referred to as the "Regional Guidance Manual." The Regional Guidance Manual provides specifications for the use of local or appropriate test species in biological tests and identifies chemical contaminants of concern.

As required by the Regional Guidance Manual, the evaluation of proposed dredged material from MOTBY consisted of bulk sediment chemical analyses and a benthic acute toxicity test. Individual sediment core samples collected from MOTBY were analyzed for grain size, moisture content, and total organic carbon (TOC). A composite sediment sample, representing the entire area proposed for dredging, was analyzed for grain size, moisture content, and TOC. The two sediment composites MT-A and MT-B were tested for benthic acute toxicity using the amphipod Ampelisca abdita. Both composites were also tested in 28-day bioaccumulation tests with the deposit-feeding clam Macoma nasuta and the suspension-feeding clam Tapes japonica. 


\subsection{Project Background}

The proposed MOTBY project area is shown in Figure 1.1. The project requires dredging and disposal of an estimated 200,000 cu yd of sediment. Project depth of Berths N1, N2, S1, and S2 (samples B-8 through B-12) is $-36 \mathrm{ft}$ plus $2 \mathrm{ft}$ of overdepth; project depth of Berths N3 through N10 (samples A-1 through A-6 and B-7) is $-35 \mathrm{ft}$ plus $2 \mathrm{ft}$ of overdepth. MOTBY was evaluated concurrently with sediments collected from the Liberty Island Anchorage. Sediment samples from these waterways were collected during a survey that took place from June 7 through June 10, 1994. This sampling and testing effort became known as New York-3 Program. Combining sample collection and evaluation of multiple dredged material projects was more costeffective for the USACE-NYD because the expense of reference site testing and quality control analyses could be shared between project budgets.

MOTBY sediment was previously sampled and tested for disposal at the Mud Dump Site by the Battelle/Marine Sciences Laboratory (MSL) in 1993 (Barrows et al. 1996). Because USACE-NYD determined that the previously performed bioassays could have reflected greater test organisms mortality due to high levels of unpurged ammonia, it requested the MSL to retest MOTBY sediments according to new protocols by EPA for reducing pore water ammonia to monitor levels before test initiation (EPAUSACE 1993; EPA 1994). The updated method calls for "purging" ammonia from test sediment in which elevated pore water ammonia concentrations are present by daily renewal of the overlying water. Once ammonia concentrations reach acceptable levels ( $<30 \mathrm{mg} / \mathrm{L}$ total ammonia for $A$. abdita) the test organisms are introduced, initiating the test. These ammonia levels are maintained throughout the test by renewing overlying water daily or as needed, at a rate not to exceed two test chamber exchanges per day.

\subsection{Organization of this Report}

Following this introduction, Section 2 presents the methods and materials used for sample collection, sample processing, sediment sample analysis of physical and chemical parameters, and quality assurance. Results of all physical/chemical analyses and bioassays are presented in Section 3. A discussion of the results and conclusions are provided in Section 4. Section 5 lists the literature cited in this report. Appendix A contains tabulated quality control data for all physical and chemical sediment analyses. Appendix $B$ contains raw data associated with the benthic acute toxicity test with $A$. abdita, such as water quality measurements, test animal survival data, and results of reference toxicant tests. Appendix $C$ contains survival data and water quality measurements for the bioaccumulation tests, and results of reference toxicant tests with $M$. nasuta and $T$. japonica. 


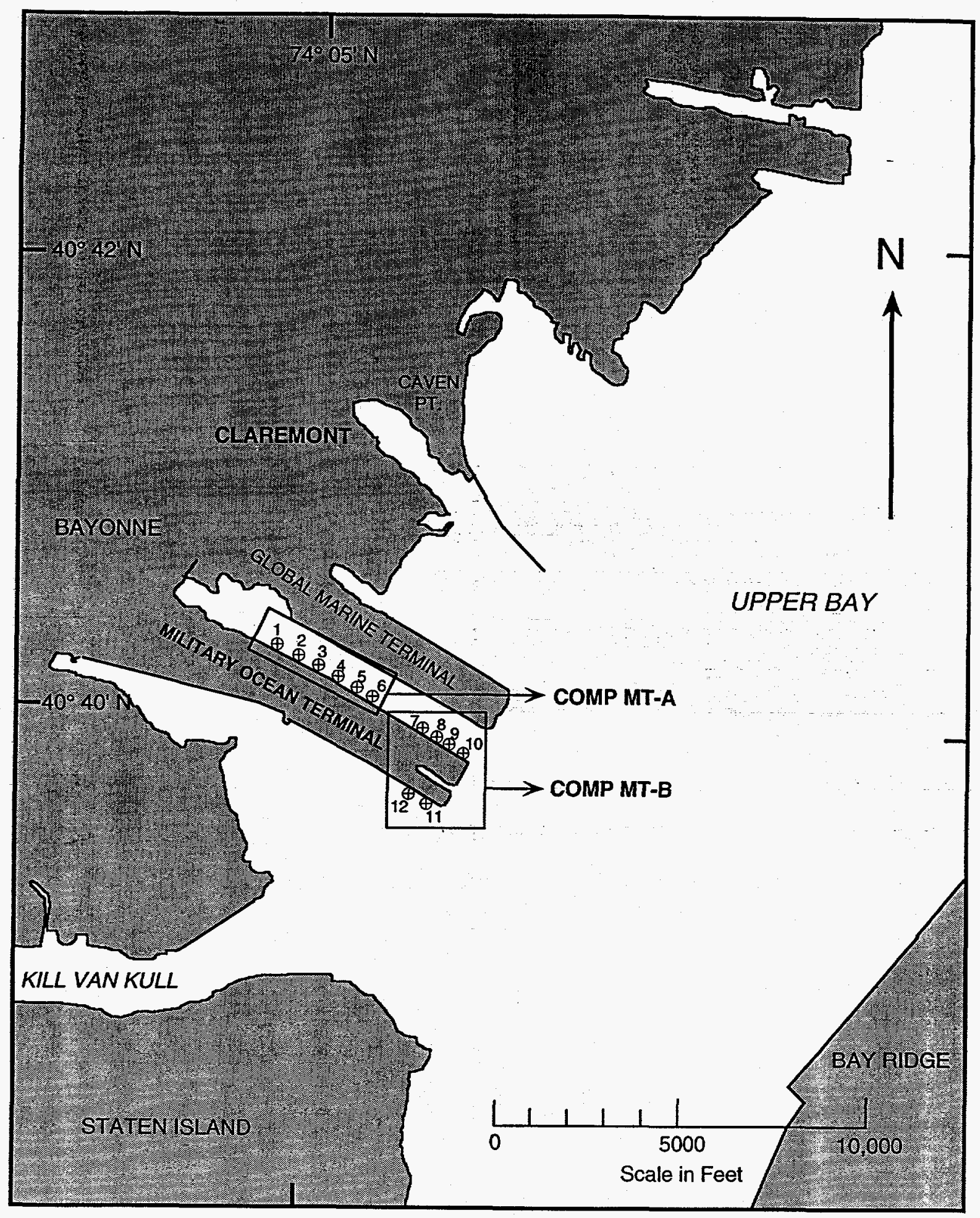




\subsection{Materials and Methods}

\subsection{Sediment Collection}

Sediment samples were collected from 12 stations within MOTBY. Sampling locations were selected by the USACE-NYD based on recent bathymetric surveys, and approximated the 1993 sampling locations. The locations, their coordinates, and core sampling depths are presented with the sampling results in Section 3.0. Reference sediment was collected from the Mud Dump Reference Site. All MOTBY samples were collected aboard the MN Driftmaster, which is owned and operated by USACE-NYD at Caven Point, New Jersey.

\subsubsection{Test Sediment Sampling}

Test sediment core samples were collected using a vibracore sampler deployed from the Driftmaster. The approximate sampling locations were first determined by reference to landmarks, such as shoreline features or buoys, as well as by water depth. Then, a hand-held Magellan Global Positioning System (GPS) was used to identify and record (within $30 \mathrm{~m}$ ) each sampling station. The vessel's LORAN was available as a backup system. Water depth at the time of sampling was measured by a fathometer on the ship. The actual water depth was corrected to mean low water (MLW) depth by correcting to the tide height at the time the depth was recorded. The difference between the MLW depth and the project depth; plus $2 \mathrm{ft}$ overdepth; equalled the amount of core required.

Core samples were collected aboard the Driftmaster using a vibracore sampler owned and operated by Ocean Surveys, Inc., Old Saybrook, Connecticut. The vibracore consisted of a 4in. outer diameter (OD), steel core barrel attached to an electric vibratory hammer. The vibratory hammer could be fitted to steel core barrels of various lengths, depending on the length of core needed. To collect a core sample, the core barrel was fitted with a 3.125-in. interior diameter (ID), steam-cleaned, Lexan polycarbonate tube. The vibracore was then suspended by the ship's crane. Once the coring apparatus was directly above the sampling station, the core was lowered through the water to the sediment surface. At this point, the station coordinates were recorded from the Magellan GPS, and water depth was recorded from the ship's fathometer. The vibratory hammer was switched on until the corer penetrated through the sediment to the desired project depth. Adequate penetration was determined relative to marks on the outside of the core barrel and on the cable suspending the vibracore from the crane. The vibracore apparatus was then pulled out of the sediment and lowered onto the ship's deck. A cutter-head and core-catcher assembly prevented loss of the sediment through the bottom of the core liner. After each core was brought on board, the liner was pulled from the barrel and the length of cored sediment was 
measured from the mudline to determine whether the appropriate depth had been reached. If not, the liner was replaced and a second core sample was attempted. If the sediment core length achieved project depth plus $2 \mathrm{ft}$ overdepth, it was capped, sealed with tape, and labeled. As cores were collected, they were shuttled back to the USACE Caven Point facility by USACE personnel in a small Boston Whaler. Cores were immediately placed in refrigerated storage $\left(\sim 4^{\circ} \mathrm{C}\right)$.

A log book was maintained containing records of each sample collected, including station designation, coordinates, replicate number, date, sampling time, water depth, core length, and number of core sections per core. Sample identification numbers were logged on chain-ofcustody forms daily.

At the conclusion of the sample collection survey, sediment cores were shipped by refrigerated van thermostatically controlled to maintain approximately $4^{\circ} \mathrm{C}$ from Caven Point, New Jersey, to the MSL in Sequim, Washington. The shipment departed from Caven Point on June 10, 1994, and arrived at the MSL on June 14, 1994.

\subsubsection{Reference and Control Sediment Sampling}

Reference sediment for toxicity and bioaccumulation tests was collected from the Mud Dump Reference Site by USACE personnel aboard the MN Cleanwaters, a vessel owned and operated by the EPA Region II. Four 5-gal containers of surficial sediment were collected using a van Veen grab sampler deployed from the Cleanwaters. After recovery, the sediments were transferred to epoxy-coated steel buckets. The buckets were covered, labeled, and stored at ambient temperature (in the shade) while aboard the ship, then were transferred to refrigerated storage at Caven Point at the end of the sampling day.

Records of reference sediment collection included coordinates, replicate number, date, sampling time, and water depth. At the conclusion of the sampling day, reference sediment samples were loaded into the refrigerated van at the staging area, and sample identification numbers were logged on chain-of-custody forms.

Native control sediments were used in each toxicity and bioaccumulation test to validate test procedures. Native sediment for $A$. abdita were supplied with the test organisms by the supplier.

\subsection{Test Organism Collection}

The amphipod $A$. abdita was supplied by East Coast Amphipod, Kingston, Rhode Island. A. abdita and its native sediment were collected from Narragansett Bay, Rhode Island, by 
dragging a large dipnet along the sediment surface. Test organisms were carefully removed from their tubes for counting, and then placed in clean, native sediment for overnight transport to the MSL.

A. abdita were shipped or transported in native sediment or under conditions designed to ensure their viability. After arrival at the MSL, the test organisms were gradually acclimated to test conditions. Animals with abnormal behavior or appearance were not used in toxicological tests. All acclimation and animal care records are part of the raw data files for these projects.

\subsection{Sediment Sample Preparation}

Sediment sample preparation consists of all steps performed in the laboratory between receipt of the samples at the MSL and the preparation of samples for biological testing and physical/chemical analyses. Sediment samples for physical, chemical, and biological analysis were prepared from individual core samples; composites of a number of core samples, reference sediment, and control sediment. All sediment samples were assigned random, unique code numbers to ensure that samples are handled without bias by staff in the biology and chemistry laboratories.

Sediment for biological testing was used within the 6-week holding period specified in the Green Book. During this holding time, the sediment samples were received at the MSL; inventoried against chain-of-custody forms; processed and used for the benthic toxicity test; and subsampled for sediment physical/chemical analyses. This section describes procedures followed for equipment preparation, safety considerations, and preparation of sediments for biological testing and chemical analyses.

\subsubsection{Laboratory Preparation and Safety Considerations}

All glassware, stainless-steel or titanium utensils, Nalgene, Teflon, and other laboratory containers and equipment underwent stringent cleaning procedures to avoid contamination of samples. Glassware (e.g., test containers, aquaria, sediment transfer dishes) was washed with hot water and detergent, rinsed with deionized water, then soaked in a $10 \%$ solution of reagent grade nitric acid for a minimum of $4 \mathrm{~h}$ and rinsed again with deionized water before it was allowed to air dry. Glassware was then rinsed with methylene chloride and allowed to dry under a fume hood. Polyvinyl chloride (PVC), Nalgene, and Teflon tools were treated in the same manner as glassware. Stainless-steel bowls, spoons, spatulas, and other utensils were washed with hot water and detergent, rinsed with deionized water, and allowed to air dry. They were then solvent-rinsed with methylene chloride and allowed to dry under a fume hood. 
Neoprene stoppers and polyethylene sheets or other porous materials were washed with hot water and detergent and rinsed with deionized water. These items were then "seasoned" by continuous soaking in $0.45-\mu \mathrm{m}$ filtered seawater for at least 2 days prior to use. Large pieces of laboratory equipment, such as the epoxy-coated sediment mixer, were washed with a dilute solution of detergent, and thoroughly rinsed with tap water followed by deionized water.

Equipment used for determining water quality, including the meters for $\mathrm{pH}$, dissolved oxygen (DO), temperature, and salinity, were calibrated according to the manufacturers' specifications and internal MSL standard operating procedures (SOPs).

Because the potential toxicity of the MOTBY sediment was unknown, sediment processing and testing were segregated from other laboratory activities. Specific areas at the MSL were established for sample storage and for core-cutting, sediment mixing, and sediment sieving. Work areas were covered with plastic sheeting to contain any waste sediment. Wastewater generated during all operations was retained in 55-gal barrels and periodically pumped through activated charcoal filters and into the MSL's wastewater treatment system. These procedures minimized any potential for cross-contamination of sediment samples.

Laboratory staff members were protected by personal safety equipment such as Tyvek suits, plastic aprons, and rubber gloves:-Those who were likely to have the most exposure to the potential volatile compounds in the bulk sediment (i.e., those responsible for opening, homogenizing, and compositing core samples) were also provided with half-mask respirators.

\subsubsection{Preparation of Sediment for Benthic Testing and Bulk Sediment Analyses}

Each Lexan core liner was opened by cutting the core longitudinally with a saw to expose the sediment. As each sediment core sample was opened, it was examined for physical characteristics (e.g., sediment type and consistency, color, odor). In particular, the presence of any strata in the cores was noted. All core observations were recorded in the sediment preparation log book. The sediment between the mudline and project depth was then transferred from the core liner to a clean, stainless-steel bowl by scooping the sediment from the core liner with a spoon or spatula. The sediment was mixed by hand with stainless-steel utensils until the color and consistency appeared homogenous, creating a sample representative of the individual sampling station. Sieving the test sediment was not necessary because no organisms were present in the sediment samples.

Aliquots of the homogenized sediment were then transferred to the appropriate sample jar(s) for physical or chemical analyses required on individual core samples. A portion of each homogenized core sample was also retained as an archive sample. The remainder of the homogenized sediment from the individual core stations was combined to create two composite 
samples representing the entire MOTBY project area, designated COMP MT-A and COMP MT-B. The composite sediment was homogenized in an epoxy-coated mixer. Aliquots of homogenized composite sediment were transferred to the appropriate sample jar(s) for physical or chemical analyses required on the composite sample. A portion of the homogenized composited sediment was also retained as an archive sample. The remainder was stored in labeled epoxy-coated buckets, tightly covered, at $4^{\circ} \mathrm{C} \pm 2^{\circ} \mathrm{C}$ until use for the benthic toxicity test.

The Mud Dump Reference Site sediment was also homogenized in the large, epoxycoated mixer, but prior to mixing, it was pressed through a 1-mm mesh to remove live organisms that might affect the outcome of toxicity tests. After mixing, aliquots for physical and chemical analyses were removed. Native control sediments for $A$. abdita were sieved through a $0.5-\mathrm{mm}$ mesh to remove live organisms and then mixed in stainless-steel bowls. All reference and control sediments were stored at $4^{\circ} \mathrm{C}+2^{\circ} \mathrm{C}$ until used in the benthic toxicity test.

\subsection{Physical and Chemical Analytical Procedures}

Individual sediment cores, COMP MT-A, COMP MT-B, reference and control sediments were analyzed for selected physical and chemical parameters. Table 2.1 is a list of the parameters measured, the method used for each analysis, and the target analytical detection limits. The following sections briefly describe the procedures used for physical and chemical analyses. Procedures followed those required by the Regional Guidance Manual unless otherwise noted.

\subsubsection{Grain Size and Moisture Content}

Grain size was measured following two methods described by Plumb (1981). The wet sieve method was used to determine the size distribution of sand or coarser-grained particles larger than a U.S. No. 230 standard sieve (62.5- $\mu \mathrm{m}$ mesh). The size distribution of particles smaller than a U.S. No. 230 sieve was determined using the pipet method. Grain size was reported as percentages within four general size classes:

$\begin{array}{ll}\text { gravel } & >2.0 \mathrm{~mm} \\ \text { sand } & 2.0-0.0625 \mathrm{~mm} \\ \text { silt } & 0.0625-0.0039 \mathrm{~mm} \\ \text { clay } & <0.0039 \mathrm{~mm} .\end{array}$

Moisture content was obtained using the Plumb (1981) method for determining total solids. The procedure involves drying a sediment sample at $100^{\circ} \mathrm{C}$ until a constant weight is obtained. Moisture content was calculated by subtracting the percentage of total solids from 100 . 
TABLE 2.1. List of Analytes, Methods, and Target Detection Limits

Analyte

Grain Size

Percent Moisture

TOC
Method

Plumb (1981)

Plumb (1981)

EPA (1986)
Detection Limit (a)

$1.0 \%$

$\mathrm{NA}(\mathrm{b})$

$0.1 \%$

(a) Detection limits are in dry weight.

(b) Not applicable.

\subsubsection{TOC}

Samples were analyzed for TOC according to an EPA Edison, New Jersey, laboratory procedure (EPA 1986). Inorganic carbon was removed from the sediment sample by acidification. The sample was combusted, and the evolved carbon dioxide was quantitated using a carbonhydrogen-nitrogen ( $\mathrm{CHN}$ ) analyzer. TOC was reported as a percentage of the dry weight of the unacidified sample.

\subsection{Biological Testing Procedures}

\subsubsection{Benthic Acute Toxicity Test with Ampelisca abdita}

Deposited sediment effects of open-water dredged material disposal were evaluated by the benthic acute toxicity test with the amphipod, $A$. abdita. Upon receipt, the $A$. abdita were placed in a tub of clean sand from their collection area and gradually acclimated with flowing Sequim Bay seawater from $28 \%$ to $30.5 \%$, over a period of 2 days. $A$. abdita were received at approximately $11^{\circ} \mathrm{C}$ and acclimated to $20^{\circ} \mathrm{C} \pm 2^{\circ} \mathrm{C}$ over 4 days. They were held at $20^{\circ} \mathrm{C} \pm 2^{\circ} \mathrm{C}$ for 1 day and were not fed prior to testing.

The amphipod test was performed in 1-L glass jars modified for use as static-renewal test chambers. The test chambers were fitted with funneled lids and screened outflow and overflow ports (Figure 2.1). The flow-through system was tumed on periodically, long enough to deliver the seawater at a rate of two chamber exchanges per day. Five replicates of COMP MT-A, COMP MT-B, Mud Dump Reference Site, and native test animal control treatments were tested.

Concentrations of ammonia have been encountered in the pore water of sediment core samples from New York/New Jersey watenways at concentrations high enough to affect survival of amphipods in benthic toxicity tests (Barrows et al. 1996). Therefore, the amphipod test was conducted according to the ammonia protocols issued by EPA and the USACE (EPANSACE 1993). This guidance requires postponing test initiation (exposure of test animals) until pore 


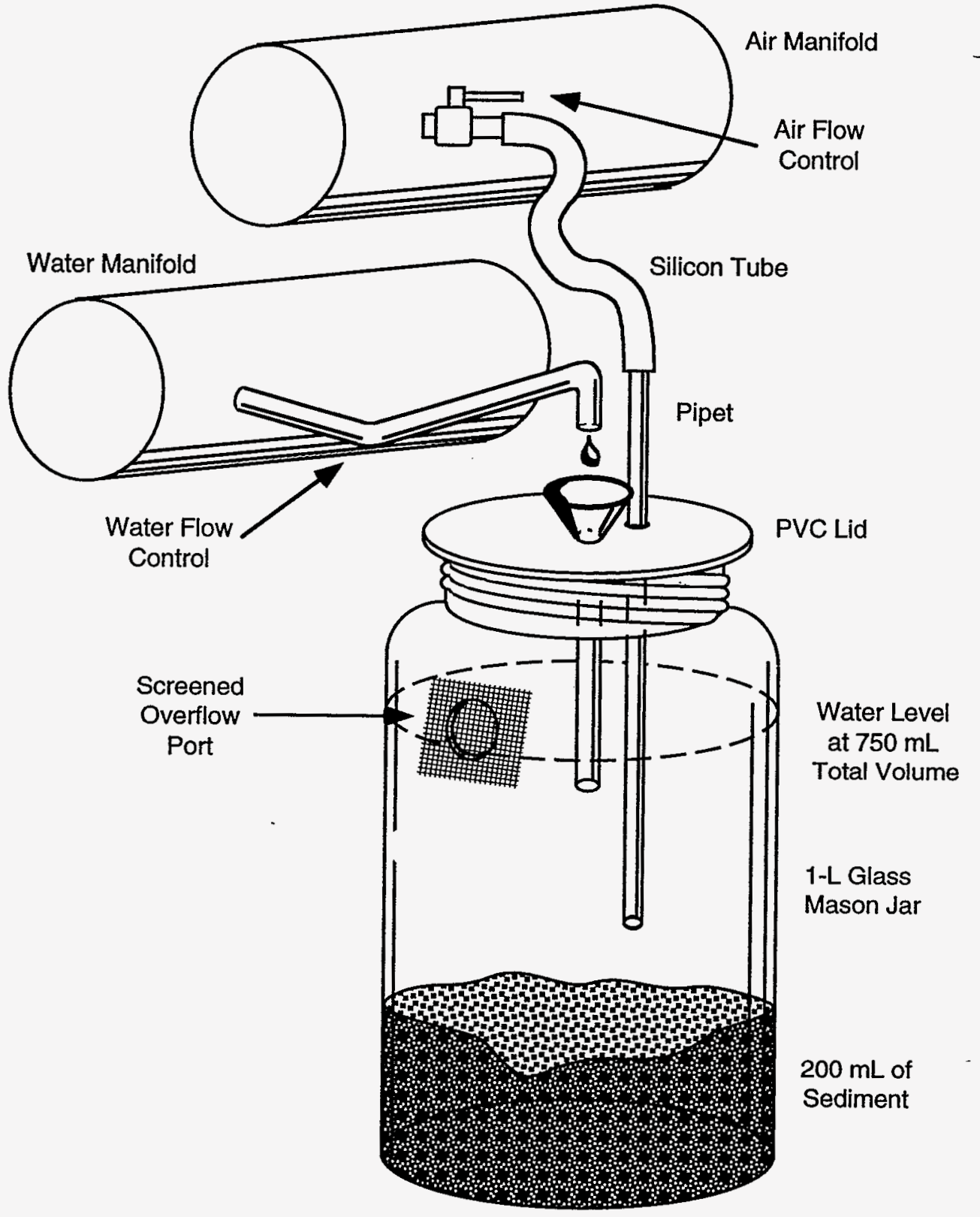

FIGURE 2.1. Testing Containers for Amphipod Static Renewal Toxicity Tests 
water total ammonia concentrations are $<30 \mathrm{mg} / \mathrm{L}$ for $A$. abdita. During this "purging" period, test chambers were set up and maintained under test conditions, and the overlying water was exchanged twice daily until the pore water ammonia concentrations reached the level appropriate for the particular amphipod. Pore water ammonia measurements were made on "dummy" containers that were set up and maintained in the same manner as the actual test containers but without animals added to them. The pore water was obtained by siphoning off the overlying water in the dummy jar and centrifuging the sediment in a Teflon jar for at least $20 \mathrm{~min}$ at approximately $3000 \mathrm{~mm}$. Salinity, temperature, and $\mathrm{pH}$ were also determined in the pore water samples.

The amphipod toxicity test was initiated by the addition of 20 organisms to each test chamber for a test population of 100 amphipods per sediment treatment. Amphipods were gently sieved from their native sediment in holding tanks and transferred to shallow baking dishes. For each test chamber, five animals were counted and transferred by pipet into each of four small, plastic cups. The animals in each transfer cup were recounted by a second observer. The animals were placed in the test chamber by dipping the cup below the surface of the water to release the amphipods.

Salinity, temperature, $\mathrm{DO}$, and $\mathrm{pH}$ were measured in all replicates prior to test initiation, in at least one replicate per treatment daily, and in all replicates at test termination. Measurements of total ammonia levels in the overlying water and pore water also continued during testing.

Overlying water ammonia was measured in all replicates prior to test initiation (Day 0), in at least one replicate per treatment daily, and in all replicates at test termination-(Day 10). Pore water ammonia was measured on Day 0 and Day 10. The following were the acceptable ranges for water quality parameters during the amphipod tests:

$\begin{array}{ll}\text { Temperature } & 20^{\circ} \mathrm{C}+2^{\circ} \mathrm{C} \\ \text { DO } & >60 \% \text { saturation (4.6 mg/L@20 } 20,30 \% \text { ) } \\ \text { pH } & 7.8 \pm 0.5 \\ \text { Salinity } & 30 \% \circ+2 \% \\ \text { Ammonia } & \leq 30 \mathrm{mg} / \mathrm{L} \\ \text { Renewal Rate } & 2 \text { exchanges/day. }\end{array}$

Gentle aeration was provided throughout the test, and the amphipods were not fed during testing. At the end of the 10-day period, the contents of each chamber were gently sieved through 0.5-mm mesh, and the number of live, dead, and missing amphipods was recorded on termination forms. An animal was considered dead if it did not respond to gentle probing. As a quality control check, a second observer confirmed surviving test organisms on at least $10 \%$ of the termination counts.

A reference toxicant test with cadmium chloride was performed concurrently with testing. The reference toxicant test was a 96-h, water-only exposure that was otherwise conducted 
following the same procedures as for the static-renewal test with sediment. $A$. abdita were exposed to nominal concentrations of $0,0.19,0.38,0.75$, and $1.5 \mathrm{mg} / \mathrm{L} \mathrm{Cd}$.

\subsubsection{Bioaccumulation Tests}

Two species of clams were used to evaluate the bioaccumulation potential of contaminants from dredged material. $M$. nasuta and $T$. japonica were exposed to two MOTBY composites, Mud Dump Reference Site sediment, and native control sediment. Five replicates per treatment were tested. Each replicate was a 10-gal, flow-through aquarium containing 25 clams. Water quality parameters (temperature, $\mathrm{DO}, \mathrm{pH}$, and salinity) were measured in all replicates at test initiation, in at least one replicate per treatment daily, and in all replicates at test termination. Flow rates were measured daily in all chambers. The acceptable ranges for water quality parameters during the bioaccumulation tests with both species were as follows:

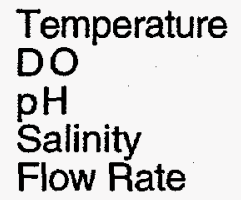

Temperature

$\mathrm{pH}$

Flow Rate

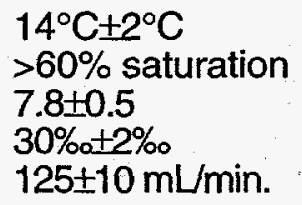

Aeration was provided to all test chambers to consistently maintain DO concentration. Water quality, organism behavior (e.g., burrowing and feeding activity) and organism mortality were recorded daily. Dead organisms were removed daily. At the end of the 28-day exposure period, $M$. nasuta and $T$. japonica were gently sieved from the sediment. Surviving clams transferred to clean flowing seawater and allowed to depurate for $24 \mathrm{~h}$. After the depuration period, the clam tissues were separated from the shells and transferred into appropriate containers for chemical analysis. Tissue samples were not analyzed as part of this project, but were frozen immediately after collection and archived frozen $\left(-20^{\circ} \mathrm{C}\right)$ for possible future analyses.

Water-only reference toxicant tests (96-h) were also performed using copper sulfate in six geometrically increasing concentrations. The exposures were conducted using a test volume of $5 \mathrm{~L}$ in static 9.5-L (2.5-gal) aquaria. Three replicates of each concentration were tested, each containing 10 organisms. Water quality parameters were monitored at the same frequency and maintained within the same limits as the 28-day test, except that there were no flow rates. The $M$. nasuta and $T$. japonica reference toxicant tests were conducted with treatments of $0,0.05$, $0.075,0.15,0.2,0.25$, and $0.30 \mathrm{mg} / \mathrm{L} \mathrm{Cu}$. 


\subsection{Data Analysis and Interpretation Procedures}

Statistical analyses were conducted to determine the magnitude and significance of toxicity in test treatments relative to the reference treatment. Each statistical test was based on a completely random design that allowed unbiased comparison among treatments.

\subsubsection{Randomization}

The $A$. abdita benthic toxicity test was designed as a completely random test. Organisms were randomly allocated to treatments, and treatments were randomly positioned on water tables. To determine randomization, a random-number table was generated for the test using the discrete random-number generator in Microsoft Excel spreadsheet software.

\subsubsection{Statistical Analysis of the Benthic Toxicity Test}

Benthic toxicity of all sediment treatments was compared by analysis of variance (ANOVA) on the arcsine square root of the proportion of organisms surviving the test. The arcsine square root transformation stabilizes the within-class variances to help meet assumptions of the ANOVA. The Green Book recommends Dunnett's test (Dunnett 1964) for comparing test treatments with a single reference treatment. The comparison of all test treatments with the reference site was performed using Dunnett's test with an experiment-wise error of $\alpha=0.05$.

\subsection{Quality Assurance/Quality Control Procedures}

The quality assurance/quality control (QAVC) procedures for the MOTBY project were consistent with the Regional Guidance Manual and the Green Book, and were documented in the Work/Quality Assurance Project Plan, Evaluation of Dredged Material Proposed for Ocean Disposal from Federal Projects at Liberty Island Anchorage and MOTBY, New York, prepared by the MSL and submitted to the USACE-NYD for this program. This document describes all QAVC procedures that were followed for sample collection, sample tracking and storage, and physical/chemical analyses. A member of Pacific Northwest National Laboratory's (PNNL) quality engineering staff was present throughout all phases of this program to observe procedures, review and audit data, and ensure that accepted protocols were followed. Laboratory notebooks or data accumulation notebooks were assigned to each portion of these studies and served as records of day-to-day project activities. 


\subsection{Results}

This section presents results of sample collection and processing, physical and chemical analyses, and biological testing conducted on sediment samples collected from the proposed MOTBY dredging area.

\subsection{Sample Collection and Processing}

Sediment core samples were collected from the MOTBY project area on June 7 through June 10, 1994. Table 3.1 lists each sampling station within the MOTBY project area, collection date, sampling coordinates, length of core required for testing, and length of core actually collected. All of the MOTBY sediments were collected aboard the Driftmaster. Two core samples were collected to project depth plus $2 \mathrm{ft}$ of overdepth from 12 sampling stations.

Upon delivery of the sediment core samples to the MSL on June 14, 1994, samples were prepared for the physical and chemical analyses according to the procedures described in Section 2. Individual sediment core samples and two composite samples were analyzed for grain size, moisture content, and TOC.

\subsection{Physical and Chemical Analyses}

\subsubsection{Sediment Core Sample Description}

Table 3.2 lists physical characteristics of each sediment core sample that was examined.

\subsubsection{Grain Size and TOC}

Table 3.3 shows the results of the analysis of MOTBY sediment samples for grain size and moisture content. A quality control summary and associated quality control data for grain size and TOC measurements are provided in Appendix A.

MOTBY sediments were predominantly silt and clay, but several samples contained gravel and pebbles (MT-A-5, MT-B-9). Percentages of sand ranged from $5 \%$ to $58 \%$; silt ranged from $13 \%$ to $56 \%$; and clay ranged from $12 \%$ to $45 \%$. These ranges do not include grain size data for subsamples taken from core prior to homogenization. The moisture content ranged from $23 \%$ to $64 \%$, except for the subsample of very stiff red clay with pebbles taken from a distinctive layer in MT-A-5, which had $10 \%$ moisture. TOC measurements for MOTBY sediments ranged from $1.6 \%$ to $5.0 \%$. 
TABLE 3.1. Summary of Sediment Sample Data for MOTBY

\begin{tabular}{|c|c|c|c|c|c|c|c|}
\hline \multirow[b]{2}{*}{ Station } & \multirow[b]{2}{*}{ Replicate } & \multirow{2}{*}{$\begin{array}{c}\text { Collection } \\
\text { Date }\end{array}$} & \multicolumn{2}{|c|}{ Station Coordinates } & \multirow{2}{*}{$\begin{array}{l}\text { Core Length } \\
\text { Required (ft) }\end{array}$} & \multirow{2}{*}{$\begin{array}{l}\text { Core Length } \\
\text { Collected (ft) }\end{array}$} & \multirow{2}{*}{$\begin{array}{l}\text { Mualine } \\
\text { Depth } \\
\text { (ft MLW) }\end{array}$} \\
\hline & & & Latitude $\mathrm{N}$ & Longitude W & & & \\
\hline MT-A-1 & 1 & $6 / 8 / 94$ & $40^{\circ} 40.22$ & $74^{\circ} 05.35$ & 2.0 & 3.0 & 35.0 \\
\hline MT-A-1 & 2 & $6 / 8 / 94$ & $40^{\circ} 40.22$ & $74^{\circ} 05.34$ & 2.7 & 2.7 & 34.3 \\
\hline MT-A-2 & 1 & $6 / 8 / 94$ & $40^{\circ} 40.17$ & $74^{\circ} 05.15$ & 4.5 & 4.5 & 32.5 \\
\hline MT-A-2 & 2 & $6 / 8 / 94$ & $40^{\circ} 40.17$ & $74^{\circ} 05.22$ & 5.0 & 5.0 & 32.0 \\
\hline MT-A-3 & 1 & $6 / 8 / 94$ & $40^{\circ} 40.17$ & $74^{\circ} 05.22$ & 5.7 & 6.0 & 31.3 \\
\hline MT-A-3 & 2 & $6 / 8 / 94$ & $40^{\circ} 40.17$ & $74^{\circ} 05.22$ & 5.6 & 5.6 & 31.4 \\
\hline MT-A-4 & 1 & $6 / 8 / 94$ & $40^{\circ} 40.19$ & $74^{\circ} 04.80$ & 5.8 & 6.0 & 31.2 \\
\hline MT-A-4 & $2^{(a)}$ & $6 / 8 / 94$ & $40^{\circ} 40.18$ & $74^{\circ} 04.89$ & 6.2 & 5.0 & 30.8 \\
\hline MT-A-4 & 3 & $6 / 9 / 94$ & $40^{\circ} 40.16$ & $74^{\circ} 04.89$ & 6.0 & 6.7 & 31.0 \\
\hline MT-A-5 & 1 & $6 / 9 / 94$ & $40^{\circ} 40.10$ & $74^{\circ} 04.77$ & 6.4 & 6.0 & 30.6 \\
\hline MT-A-5 & 2 & $6 / 9 / 94$ & $40^{\circ} 40.14$ & $74^{\circ} 04.77$ & 6.7 & 6.7 & 30.3 \\
\hline MT-A-6 & 1 & 6/9/94 & $40^{\circ} 40.10$ & $74^{\circ} 04.65$ & 5.5 & 4.6 & 31.5 \\
\hline MT-A-6 & 2 & $6 / 9 / 94$ & $40^{\circ} 40.10$ & $74^{\circ} 04.69$ & 5.9 & 6.3 & 31.1 \\
\hline MT-B-7 & 1 & $6 / 9 / 94$ & $40^{\circ} 39.94$ & $74^{\circ} 04.38$ & 6.6 & 8.0 & 30.4 \\
\hline MT-B-7 & 2 & $6 / 9 / 94$ & $40^{\circ} 39.96$ & $74^{\circ} 04.41$ & 7.8 & 7.8 & 29.2 \\
\hline MT-B-8 & 1 & 6/9/94 & $40^{\circ} 39.94$ & $74^{\circ} 04.36$ & 6.6 & 7.0 & 31.4 \\
\hline MT-B-8 & 2 & $6 / 9 / 94$ & $40^{\circ} 39.89$ & $74^{\circ} 04.32$ & 6.6 & 8.0 & 31.4 \\
\hline MT-B-9 & 1 & $6 / 9 / 94$ & $40^{\circ} 39.89$ & $74^{\circ} 04.24$ & 8.6 & 8.6 & 29.4 \\
\hline MT-B-9 & 2 & $6 / 9 / 94$ & $40^{\circ} 39.91$ & $74^{\circ} 04.26$ & 7.1 & 8.0 & 30.9 \\
\hline MT-B-10 & 1 & 6/9/94 & $40^{\circ} 39.84$ & $74^{\circ} 04.18$ & 4.5 & 4.5 & 33.5 \\
\hline MT-B-10 & 2 & $6 / 9 / 94$ & $40^{\circ} 39.85$ & $74^{\circ} 04.15$ & 4.8 & 4.8 & 33.2 \\
\hline MT-B-11 & 1 & $6 / 9 / 94$ & $40^{\circ} 39.63$ & $74^{\circ} 04.36$ & 4.2 & 5.0 & 33.8 \\
\hline MT-B-11 & 2 & $6 / 9 / 94$ & $40^{\circ} 39.63$ & $74^{\circ} 04.35$ & 3.9 & 5.0 & 34.1 \\
\hline MT-B-12 & 1 & $6 / 9 / 94$ & $40^{\circ} 39.71$ & $74^{\circ} 04.50$ & 3.1 & 3.1 & 34.9 \\
\hline MT-B-12 & 2 & $6 / 9 / 94$ & $40^{\circ} 39.71$ & $74^{\circ} 04.49$ & 3.0 & 3.0 & 34.0 \\
\hline
\end{tabular}

(a) MT-A-4 Rep 2 was too short to use for testing; a third replicate was collected the next day. 
TABLE 3.2. MOTBY Sediment Core Descriptions

\begin{tabular}{|c|c|c|c|c|}
\hline \multirow[b]{2}{*}{ Station } & \multicolumn{3}{|c|}{ Depth (-ft MLW) } & \multirow[b]{2}{*}{ Sediment Core Description } \\
\hline & Core Top & Core Bottom & $\begin{array}{l}\text { Project } \\
\text { Depth }\end{array}$ & \\
\hline MT-A-1 Rep 1 & 34.3 & 40.0 & 37.0 & $\begin{array}{l}\text { Uniform dark gray, silty clay from mudline to project depth; } \\
-39.0 \text { to }-40.0 \mathrm{ft} \text { MLW cast } 1 \mathrm{ft} \text { red clay. Rep } 2 \text { same } \\
\text { appearance as Rep } 1 .\end{array}$ \\
\hline MT-A-2 Rep 1 & 32.5 & 37.0 & 37.0 & $\begin{array}{l}\text { Uniform soft, black, silty clay with sulfide smell from mudline } \\
\text { to }-35.8 \mathrm{ft} \text { MLW. Black oily sand from }-35.0 \text { to }-35.8 \mathrm{ft} \text { MLW. } \\
\text { More dense clayey material from }-35.8 \text { to }-37.0 \mathrm{ft} \text { MLW. Rep } \\
2 \text { same appearance as Rep } 1 \text {. }\end{array}$ \\
\hline MT-A-3 Rep 1 & 31.3 & 37.0 & 37.0 & $\begin{array}{l}\text { Black silty, clayey material with sulfide and oily odor from } \\
\text { mudline to }-33.7 \mathrm{ft} M L W \text {. Oily, sandy material from }-33.7 \text { to } \\
-34.0 \mathrm{ft} \mathrm{MLW} \text {. Dense, black clayey material from }-34.0 \text { to } \\
-37.0 \mathrm{ft} \mathrm{MLW} \text {. Rep } 2 \text { same appearance as Rep } 1 \text {. }\end{array}$ \\
\hline MT-A-4 Rep 1 & 31.2 & 37.0 & 37.0 & $\begin{array}{l}\text { Uniform black, silty, clayey material from mudline to project } \\
\text { depth. }\end{array}$ \\
\hline MT-A-4 Rep 2 & 31.0 & 37.0 & 37.0 & $\begin{array}{l}\text { Uniform black; silty, clayey material from mudline to }-34.5 \mathrm{ft} \\
\text { MLW. 4-in. band of red clay }-34.4 \text { to }-34.8 \mathrm{ft} \text { MLW. Gray } \\
\text { sandy clay }-34.8 \text { to }-37.0 \mathrm{ft} \text { MLW. }\end{array}$ \\
\hline MT-A-5 Rep 1 & 30.6 & 36.5 & 37.0 & $\begin{array}{l}\text { Uniform dark, black, silty clay material from mudline to } \\
-35.5 \mathrm{ft} \text { MLW. Thin band of gray clay from }-34.8 \text { to }-34.9 \mathrm{ft} \\
\text { MLW. Red clay from }-35.5 \text { to }-36.5 \mathrm{ft} \text { MLW. }\end{array}$ \\
\hline MT-A-5 Rep 2 & 30.3 & 37.0 & 37.0 & $\begin{array}{l}\text { Uniform black, silty, clayey material from mudline to }-34.8 \mathrm{ft} \\
\text { MLW. Red clay }-34.8 \text { to }-37.0 \mathrm{ft} \text { MLW. }\end{array}$ \\
\hline MT-A-6 Rep 1 & 31.1 & 37.0 & 37.0 & $\begin{array}{l}\text { Uniform black, silty, clayey material from mudline to bottom } \\
\text { of core. Rep } 2 \text { had } 6 \text { in. red clay at bottom }(-36.8 \text { to }-37.3 \mathrm{ft} \\
\mathrm{MLW}) \text {. }\end{array}$ \\
\hline MT-B-7 Rep 1 & 30.4 & 39.2 & 37.0 & $\begin{array}{l}\text { Soft, black silt material from mudline to }-32.4 \mathrm{ft} \mathrm{MLW.} \mathrm{From} \\
-32.4 \text { to }-34.0 \mathrm{ft} \text { MLW, there were bands of } 2 \text { in. black sand, } \\
\text { then } 4 \text { in. silty clay, then } 2 \text { in. black sand, then } 6 \text { in. black, } \\
\text { rocky sand and silt, then } 2 \text { in. sand with oil. Dense black clay } \\
\text { from }-34.0 \text { to }-37.0 \mathrm{ft} \text { MLW. Rep } 2 \text { same appearance as } \\
\text { Rep } 1 .\end{array}$ \\
\hline
\end{tabular}

$\begin{array}{llll}\text { MT-B-8 Rep } 1 \quad 31.4 & 38.0 & 38.0\end{array}$

Approximately 6 in. of soft silt at top of core then $1.5 \mathrm{in}$. of gray clay. Remainder of core consisted of uniform black, silty, clayey material. Rep 2 same appearance as Rep 1 except no thin layer of gray clay.

MT-B-9 Rep $1 \quad 29.4 \quad 35.3 \quad 38.0$

Soft, black silt to $-30 \mathrm{ft}$ MLW, then 2-in. gray clay layer. Black sand interspersed with patches of black silty clay -30.2 to $-32.3 \mathrm{ft} \mathrm{MLW}$. Black, silty clay with streaks of oil 32.3 to $-34.0 \mathrm{ft}$ MLW; gray sand, gravel, and rocks -34.0 to $-35.3 \mathrm{ft}$ MLW. 
TABLE 3.2. (contd)

Depth (-ft MLW)

Station

MT-B-9 Rep 2

MT-B-10 Rep 1

MT-B-11 Rep 1

MT-B-12 Rep 1
Project

Core Top Core Bottom

30.9

38.0

38.0

33.5

38.0

38.0

33.8

38.0

38.0

34.9

38.0

38.0
Sediment Core Description

Loose, watery silt from mudline to $-32.0 \mathrm{ft} \mathrm{MLW.} \mathrm{Black,}$ silty-clayey material from -32.0 to $-33.0 \mathrm{ft} \mathrm{MLW}$. Brown sand with rocks from -33.0 to $-38.0 \mathrm{ft} \mathrm{MLW}$ with a thin layer of rocks at $-34.5 \mathrm{ft} \mathrm{MLW}$ and large rocks from -36.5 to $-38.0 \mathrm{ft}$ MLW. Approximately 2 in. band of red clay at $-37.5 \mathrm{ft}$ MLW.

Uniform black, silty-clayey material from mudline to project depth. Rep. 2 has same appearance with slightly softer material.

Uniform black, silty-clayey material from mudline to project depth.

Uniform black, silty-clayey material from mudline to project depth. Rep 2 same appearance as Rep 1. 
IABLE 3.3. Results of Analysis of MOTBY Sediment Samples for Grain Size, MoistureContent, and TOC

\begin{tabular}{|c|c|c|c|c|c|c|}
\hline \multirow[b]{2}{*}{ Station } & \multicolumn{4}{|c|}{ Total Percent (dry weight) } & \multirow[b]{2}{*}{$\begin{array}{l}\text { Moisture } \\
\% \text { wet wt }\end{array}$} & \multirow[b]{2}{*}{$\begin{array}{c}\text { TOC } \\
\% \text { drywt }\end{array}$} \\
\hline & $\begin{array}{c}\text { Gravel } \\
\geq 2.0 \mathrm{~mm}\end{array}$ & 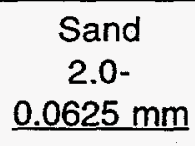 & $\begin{array}{c}\text { Silt } \\
0.063- \\
0.0039 \mathrm{~mm} \\
\end{array}$ & $\begin{array}{c}\text { Clay } \\
\leq 0.0039 \mathrm{~mm} \\
\end{array}$ & & \\
\hline MT-A-1 & 0 & 6 & 55 & 39 & 51 & 1.96 \\
\hline MT-A-2 & 1 & 13 & 52 & 34 & 51 & 2.16 \\
\hline MT-A-3 & 0 & 19 & 48 & 33 & 54 & 3.17 \\
\hline MT-A-4 & 0 & 36 & 48 & 16 & 28 & 2.27 \\
\hline MT-A-4 $(-34.8$ to $-37.0 \mathrm{ft})$ (a) & 0 & 60 & 29 & 11 & 20 & $N A(b)$ \\
\hline MT-A-4 $(-34.5$ to $-34.8 \mathrm{ft})(\mathrm{c})$ & 0 & 9 & 79 & 12 & 20 & NA \\
\hline MT-A-5 & 16 & 33 & 36 & 16 & 23 & 2.00 \\
\hline MT-A-5 $(-35.7$ to $-36.7 \mathrm{ft})(\mathrm{d})$ & 11 & 40 & 38 & 11 & 10 & NA \\
\hline MT-A-6 & 0 & 10 & 49 & 41 & 59 & 3.44 \\
\hline Comp MT-A & 1 & 23 & 41 & 35 & 51 & 2.41 \\
\hline MT-B-7 & 3 & 24 & 36 & 37 & 55 & 3.62 \\
\hline MT-B-8 & 1 & 13 & 41 & 45 & 59 & 4.32 \\
\hline MT-B-9 & 17 & 58 & 13 & 12 & 28 & 1.58 \\
\hline MT-B-10(e) & 0 & 10 & 44 & 45 & 61 & 4.99 \\
\hline MT-B-11 & 0 & 5 & 52 & 43 & 64 & 4.17 \\
\hline MT-B-12 & 0 & 5 & 56 & 39 & 64 & 4.06 \\
\hline Comp MT-B & 5 & 39 & 29 & 27 & 48 & 3.06 \\
\hline Mud Dump Reference Site & 1 & 98 & 0 & 1 & 17 & 0.006 \\
\hline A. abdita Control & 0 & 6 & 69 & 25 & 71 & 3.1 \\
\hline
\end{tabular}

(a) Sample taken from Core MT-A-4 Rep 2, -34.8 to $-37.0 \mathrm{ft} \mathrm{MLW}$, where distinctly different sediment type was observed (gray sandy clay).

(b) NA Not applicable, sample not measured for this parameter.

(c) Sample taken from Core MT-A-4 Rep 2, -34.5 to $-34.8 \mathrm{ft}$ MLW, where distinctly different sediment type was observed (red clay).

(d) Sample taken from Core MT-A-5 Rep 1, -35.7 to $-36.7 \mathrm{ft} \mathrm{MLW,} \mathrm{where} \mathrm{distinctly} \mathrm{different} \mathrm{sediment} \mathrm{type}$ was observed (stiff red clay with pebbles).

(e) Average of replicates. 


\subsection{Benthic Acute Toxicity Testing}

The only benthic acute toxicity test that was performed on the MOTBY composite sediments and Mud Dump Reference Site sediment was the amphipod $A$. abdita. Complete test results, water quality measurements, and the results of the reference toxicant tests are presented in Appendix B. Throughout this section the term "significant difference" is used to express statistically significant differences only. Tests for statistical significance between the treatment and reference treatment were performed following methods outlined in Section 2.6.

Results of the benthic toxicity test with $A$. abdita are summarized in Table 3.4. Complete test results and water quality data are presented in Appendix B. Prior to test setup, total ammonia concentrations measured in the MT-A and MT-B bulk sediment composites were $98.6 \mathrm{mg} / \mathrm{L}$ and $133 \mathrm{mg} / \mathrm{L}$, respectively. Test chambers containing sediment and overlying water were set up (June 16, 1994) and maintained under test conditions with aeration during the ammonia purging period. Overlying water was exchanged twice daily, via a flow-through system (i.e., two times each day, the seawater flow into the test chambers was turned on long enough to displace the volume of the water in the test chamber once). Pore water ammonia was measured in "dummy" jars every few days until concentrations were $30 \mathrm{mg} / \mathrm{L}$ or less. The test was initiated after 11 days (June 27,-1994) when the pore water ammonia concentration in MT-A-was $26.0 \mathrm{mg} / \mathrm{L}$ (there-were not enough "dummy" jars of MT-B to measure pore water ammonia after 11 days of purging).

Survival in the $A$. abdita control sediment was $88 \%$. After discussions with the New York District representative, this test was used to assess benthic affects of MOTBY sediments. Survival in the MT-A and MT-B composites was $86 \%$ and $71 \%$, respectively, and only that of MT-B was significantly lower than that of the Mud Dump Reference Site sediment ( $94 \%$ survival).

Water quality parameters were within acceptable ranges throughout the test, except for a few $\mathrm{pH}$ measurements that were slightly above the target range. Ammonia concentrations were less than $2.0 \mathrm{mg} / \mathrm{L}$ in the overlying water during the 10-day test, and were $3.81 \mathrm{mg} / \mathrm{L}$ in MT-A pore water and $20.0 \mathrm{mg} / \mathrm{L}$ in MT-B pore water at test termination. The Cd reference toxicant test produced an $\mathrm{LC}_{50}$ of $0.54 \mathrm{mg} / \mathrm{L} \mathrm{Cd}$, which was within the control limits established at the MSL (0.5 mg/L to $1.4 \mathrm{mg} / \mathrm{L} \mathrm{Cd}$ ). 
TABLE 3.4. Summary of Benthic Acute Toxicity Test Performed with MOTBY Sediment

Sediment Treatment

COMP MT-A

COMP MT-B

Mud Dump Reference Site

A. abdita Control

\section{Percent Survival}

86.0

71.0

94.0

88.0
Significantly Different(a)

NO
YES
NA(b)
NA

(a) Statistically significant mortality in the test treatment that is $20 \%$ greater than the reference for amphipods, as required by the Regional Guidance Manual.

(b) NA Not applicable.

\subsection{Bioaccumulation Testing}

Bioaccumulation tests with $M$. nasuta and $T$. japonica were conducted using both COMPs MT-A and MT-B, the Mud Dump Reference Site sediment, and the native control sediment for each species. All organisms were exposed for 28 days under flow-through conditions. Survival of $M$. nasuta ranged from $92 \%$ in the Mud Dump Reference Site sediment to $97 \%$ in COMP MT-A. Survival of T. japonica was $100 \%$ in all four treatments. The tissues of the surviving organisms exposed to sediment have been archived frozen should chemical analyses be requested in the future. In the Cu reference toxicant tests with $M$. nasuta and $T$. japonica, $\mathrm{LC}_{50}$ concentrations could not be estimated because there was no mortality greater than $50 \%$ in any of the test treatments (highest concentration was $2.5 \mathrm{mg} / \mathrm{L} \mathrm{Cu}$ ). A dose-response was observed with $M$. nasuta, but $50 \%$ survived the $2.5 \mathrm{mg} / \mathrm{L} \mathrm{Cu}$ treatment; $T$. japonica survival was $100 \%$ in all $\mathrm{Cu}$ concentrations. 


\subsection{Discussion and Conclusions}

In this section, physical and chemical analyses, and bioassays performed on the MOTBY sediment composite are evaluated relative to the Mud Dump Reference Site sediment by the guidelines of the Green Book Tier III. Tier III evaluations include water-column toxicity tests, benthic toxicity tests, and whole-sediment bioaccumulation studies. Tier III evaluations assess the impact of contaminants in the dredged material on marine organisms to determine whether there is potential for the material to have an unacceptable environmental effect during ocean disposal. The Green Book provides the following guidance for determining whether the proposed dredged material is unacceptable for ocean disposal based on the benthic acute toxicity test: the proposed dredged material does not meet the LPC for benthic toxicity when organism survival in the test sediment and the reference site sediment is statistically significantly different, and the decrease in survival exceeds $20 \%$ for $A$. abdita.

Sections 4.1 and 4.2 discuss the proposed MOTBY dredged material in terms of sediment characterization and Tier III evaluations.

\subsection{Sediment Physical and Chemical Characterization}

MOTBY sediment core samples were predominantly black, silty-clayey material. Percentages of silt ranged from $13 \%$ to $56 \%$, and clay ranged from $12 \%$ to $45 \%$. Sediment moisture content varied from $23 \%$ to $64 \%$ in individual cores. TOC measurements for MOTBY sediments ranged from $1.6 \%$ to $5.0 \%$.

\subsection{Toxicity}

Survival of $A$. abdita in the MT-A and MT-B composites was $86 \%$ and $71 \%$, respectively, and only MT-B was significantly lower than that of the Mud Dump Reference Site sediment ( $94 \%$ survival). Therefore, MT-B sediment did not meet the LPC for benthic toxicity to A. abdita, if the observed effects are due to persistent contaminants. 


\subsection{References}

Barrows, E.S., M.R. Pinza, W.W. Gardiner, N.P. Kohn, B.D. Gruendell, H.L. Mayhew, J.Q. Word, and L.B. Rosman. 1996. Evaluation of Dredged Material Proposed for Ocean Disposal from Federal Projects in New York and New Jersey and the Military Ocean Terminal (MOTBY). Prepared for Department of the Army, U.S. Army Corps of Engineers, New York District, Water Quality Branch by Battelle/Marine Sciences Laboratory, Pacific Northwest National Laboratory. (In preparation.)

Dunnett, C.W. 1964. "New Tables for Multiple Comparisons with a Control." Biometrics 20:482-491.

EPA (U.S. Environmental Protection Agency). 1986. Determination of Total Organic Carbon in Sediment. U.S. Environmental Protection Agency, Region II, Environmental Services Division, Monitoring Management Branch, Edison, New Jersey.

EPA (U.S. Environmental Protection Agency). 1994. Methods for Assessing the Toxicity of Sediment-associated Contaminants with Estuarine and Marine Amphipods. Office of Research and Development, Washington D.C.

EPAUUSACE (U.S. Environmental Protection Agency/U.S. Army Corps of Engineers). 1991. Evaluation of Dredged Material Proposed for Ocean Disposal (Testing Manual). EPA-503/891/001. U.S. Environmental Protection Agency, Office of Marine and Estuarine Protection, Washington, D.C.

EPAJUSACE (U.S. Environmental Protection Agency/U.S. Army Corps of Engineers). 1993. Memorandum: Technical Panel Recommendations Concerning Use of Acute Amphipod Tests in Evaluation of Dredged Material. December 21, 1993. U.S. Environmental Protection Agency/U.S. Army Corps of Engineers. Washington, D.C.

Plumb, R. H., Jr. 1981. Procedure for Handling and Chemical Analysis of Sediment and Water Samples. Tech. Rep. EPAVCE-81-1. Prepared by Great Lakes Laboratory, State University College at Buffalo, New York, for the U.S. Environmental Protection Agency/U.S. Army Corps of Engineers Technical Committee on Criteria for Dredged and Fill Material. U.S. Army Engineer Waterways Experiment Station, Vicksburg, Mississippi.

USACE-NYD/EPA Region II (U.S. Army Corps of Engineers, New York District/U.S.

Environmental Protection Agency, Region II). 1992. Guidance for Performing Tests on Dredged Material Proposed for Ocean Disposal. 18 December 1992 Draft. U.S. Army Corps of Engineers, New York District and U.S. Environmental Protection Agency, Region II. New York, New York. 


\section{Appendix A}

\section{Quality Assurance/Quality Control Data for Sediment Grain Size and TOC Analyses, MOTBY}




\section{QA/QC SUMMARY}

PROGRAM: $\quad$ New York/New Jersey Federal Projects 3

PARAMETER: Grain Size

LABORATORY: Soil Technology, Bainbridge Island, Washington

MATRIX: $\quad$ Sediment

QAVC DATA QUALITY OBJECTIVES

Reference

Method

Plumb 1981

METHOD

HOLDING TIMES

DETECTION LIMITS

METHOD BLANKS

MATRIX SPIKES

REPLICATES

SRMS

\section{Range of Recovery}

Not applicable
Relative

Precision

$\leq 20 \%$ for fractions greater than $5 \%$
Detection Limit ( $\mu \mathrm{g} / \mathrm{L})$

$1.0 \%$

Four grain size fractions were determined by a combination of sieve and pipet techniques. An additional measurement for salt content was performed, and each grain size fraction was corrected for this salt measurement.

The holding time of 6 months was met for all grain size analyses.

Target detection limits of $0.1 \%$ were met for all samples.

Not applicable.

Not applicable.

Two samples were analyzed in triplicate. Precision for triplicate analyses is reported by calculating the relative standard deviation (RSD) between the replicate results. The RSDs for both samples were within the QC limits of $\leq 20 \%$.

Not applicable.

\section{REFERENCES}

Plumb, R. H., Jr. 1981. Procedure for Handling and Chemical Analysis of Sediment and Water Samples. Tech. Rep. EPA/CE-81-1. Prepared by Great Lakes Laboratory, State University College at Buffalo, New York, for the U.S. Environmental Protection Agency/U.S. Army Corps of Engineers Technical Committee on Criteria for Dredged and Fill Material. U.S. Army Engineer Waterways Experiment Station, Vicksburg, Mississippi. 


\section{QA/QC SUMMARY}

PROGRAM:

PARAMETER:

LABORATORY:

MATRIX:
New York/New Jersey Federal Projects 3

Total Organic Carbon (TOC)

Applied Marine Sciences, Inc., College Station, Texas

Sediment

\section{QA/QC DATA QUALITY OBJECTIVES}

\begin{tabular}{c} 
Reference \\
Method \\
\hline
\end{tabular}

EPA 1986

METHOD

DETECTION LIMITS

HOLDING TIMES

METHOD BLANKS

REPLICATES

\section{Range of Recovery}

$\leq 20 \%$ \begin{tabular}{l} 
Relative \\
Precision \\
\hline
\end{tabular}

$\leq 10 \%$
Detection Limit ( $\mu \mathrm{g} / \mathrm{L})$

$0.1 \%$

Total organic carbon is the amount of non-volatile, partially volatile, volatile, and particulate organic carbon compounds in a sample. Each sample was dried and ball milled to a fine powder. Before combustion, inorganic carbon in the sample was removed by acidification. The TOC was then determined by measuring the carbon dioxide released during combustion of the sample.

Calculated method detection limit (MDL) for the coulometer was $0.1 \%$, which meets the target detection limit.

The holding time of 6 months was met for all TOC analyses.

Not applicable.

Two sample were analyzed in triplicate with the samples. Precision for triplicate analyses is reported by calculating the relative standard deviation (RSD) between the replicate results. The calculated RSDS were $0 \%$ and $1 \%$, which are within the QC limits of $\leq 10 \%$.

\section{STANDARD REFERENCE MATERIAL}

One SRM, NIST 1941a, was analyzed with each batch of samples. The values obtained for each SRM were within $30 \%$ of the certified

\section{REFERENCES} value, indicating acceptable accuracy of the method.

U.S. Environmental Protection Agency (EPA). 1986. Determination of Total Organic Carbon in Sediment. U.S. EPA Region II, Environmental Services Division, Monitoring Management Branch, Edison, New Jersey. 
TABLE A.1. Grain Size Analysis of MOTBY Sediments

\begin{tabular}{|c|c|c|c|c|c|c|c|}
\hline \multirow{3}{*}{$\begin{array}{l}\text { Sediment } \\
\text { Treatment }\end{array}$} & \multirow[b]{3}{*}{ Rep } & \multirow[b]{3}{*}{ Batch } & \multicolumn{5}{|c|}{ Total Percent (Dry) } \\
\hline & & & Gravel & Sand & Silt & Clay & Percent \\
\hline & & & $(>2.0 \mathrm{~mm})$ & $(2.0-0.063 \mathrm{~mm})$ & $(0.063-0.004 \mathrm{~mm})$ & $(<0.004 \mathrm{~mm})$ & Moisture \\
\hline MT-A-1 & 1 & 1 & 0 & 6 & 55 & 39 & 51 \\
\hline MT-A-2 & 1 & 1 & 1 & 13 & 52 & 34 & 51 \\
\hline MT-A-3 & 1 & 1 & 0 & 19 & 48 & 33 & 54 \\
\hline MT-A-4 & 1 & 1 & 0 & 39 & 37 & 24 & 45 \\
\hline MT-A-4 $(-34.8 \text { to }-37.0 \mathrm{ft})^{(\mathrm{a})}$ & 1 & 1 & 0 & 60 & 29 & 11 & 20 \\
\hline MT-A-4 (-34.5 to $-34.8 \mathrm{ft.})^{\text {(b) }}$ & 1 & 1 & 0 & 9 & 79 & 12 & 20 \\
\hline MT-A-5 & 1 & 1 & 21 & 25 & 34 & 20 & 36 \\
\hline MT-A-5 $(-35.7 \text { to }-36.7 \mathrm{ft} .)^{(\mathrm{c})}$ & 1 & 1 & 11 & 40 & 38 & 11 & 10 \\
\hline MT-A-6 & 1 & 1 & 0 & 10 & 49 & 41 & 59 \\
\hline MT-B-7 & 1 & 1 & 3 & 24 & 36 & 37 & 55 \\
\hline MT-B-8 & 1 & 1 & 1 & 13 & 41 & 45 & 59 \\
\hline MT-B-9 & 1 & 1 & 17 & 58 & 13 & 12 & 28 \\
\hline MT-B-10 & 1 & 1 & 0 & 11 & 44 & 45 & 61 \\
\hline MT-B-10 & 2 & 1 & 1 & 9 & 44 & 46 & 61 \\
\hline MT-B-10 & 3 & 1 & 0 & 10 & 45 & 45 & 60 \\
\hline MT-B-11 & 1 & 1 & 0 & 5 & 52 & 43 & 64 \\
\hline MT-B-12 & 1 & 1 & 0 & 5 & 56 & 39 & 64 \\
\hline COMP MT-A & 1 & 1 & 1 & 23 & 41 & 35 & 51 \\
\hline COMP MT-B & 1 & 1 & 5 & 39 & 29 & 27 & 48 \\
\hline Mud Dump Ref Site & & 1 & 1 & 98 & 0 & 1 & 17 \\
\hline A. abdita Control & & 1 & 0 & 6 & 69 & 25 & 71 \\
\hline \multicolumn{8}{|l|}{ Replicate Analysis } \\
\hline MT-B-10 & 1 & 1 & 0 & 11 & 44 & 45 & 61 \\
\hline MT-B-10 & 2 & 1 & 1 & 9 & 44 & 46 & 61 \\
\hline MT-B-10 & 3 & 1 & 0 & 10 & 45 & 45 & 60 \\
\hline $\operatorname{RSD}^{(\mathrm{d})}$ & & & $173 \%$ & $10 \%$ & $1 \%$ & $1 \%$ & $0 \%$ \\
\hline QC Sample (COMP LI) & 1 & 1 & 1 & 23 & 41 & 35 & 56 \\
\hline QC Sample (COMP LI) & 2 & 1 & 2 & 21 & 43 & 34 & 55 \\
\hline QC Sample (COMP LI) & 3 & 1 & 3 & 23 & 39 & 35 & 56 \\
\hline RSD & & & $50 \%$ & $5 \%$ & $5 \%$ & $2 \%$ & $2 \%$ \\
\hline
\end{tabular}

(a) Sample taken from core MT-A-4 Rep 2, -34.8 to $-37.0 \mathrm{ft}$. MLW, where distinctly different sediment types were obse

(b) Sample taken from core MT-A-4 Rep 2, -34.5 to $-34.8 \mathrm{ft}$. MLW, where distinctly different sediment types were obse

(c) Sample taken from core MT-A-5 Rep 1, -35.7 to $-36.7 \mathrm{ft}$. MLW, where distinctly different sediment types were obse

(d) RSD Relative standard deviation. 
TABLE A.2. Sediment Total Organic Carbon (TOC), MOTBY

Sediment

TOC

Treatment

Replicate

Batch (\% dry weight)

MT-A-1

MT-A-2

1.96

MT-A-3

2.16

MT-A-4

MT-A-5

MT-A-5

MT-A-5

MT-A-6

MT-B-7

MT-B-8

MT-B-9

MT-B-10

MT-B-11

MT-B-12

Mud Dump Reference

Ampelisca Control

Lepto Control

Mysid Control

Rhepox Control

$\begin{array}{ll}1 & 1.96 \\ 1 & 2.16 \\ 1 & 3.17 \\ 1 & 2.27 \\ 1 & 2.01 \\ 1 & 2.00 \\ 1 & 1.99 \\ 2 & 3.44 \\ 2 & 3.62 \\ 2 & 4.32 \\ 2 & 1.58 \\ 2 & 4.99 \\ 2 & 4.17 \\ 2 & 4.06 \\ 1 & \\ 1 & 0.006 \\ 1 & 3.10 \\ 1 & 1.50 \\ 1 & 2.42 \\ & 0.09\end{array}$

Quality Control Data

Standard Reference Material

Certified Value

4.80

$\pm 1.2 \%$

NIST 1941a

Percent Difference

1

4.74

NIST 1941a

$1 \%$

Percent Difference

4.66

$3 \%$

Triplicate Analysis

MT-A-5

MT-A-5

MT-A-5

$\mathrm{RSD}^{(\mathrm{a})}$

QC Sample (LI-3)

QC Sample (LI-3)

QC Sample (LI-3)

2.27

.99

4

.32

99

17

006

50

42

0.09

RSD

2.01

2.00

1.99

$0 \%$

3.11

3.17

3.11

$1 \%$

(a) RSD Relative standard deviation. 
Appendix B

Benthic Acute Toxicity Test Data, MOTBY 
TABLE B.1. Results for A. abdita 10-Day, Static Renewal, Benthic Acute Toxicity Test

\begin{tabular}{|c|c|c|c|c|c|c|}
\hline $\begin{array}{l}\text { Sediment } \\
\text { Treatment }\end{array}$ & Replicate & Live $^{\text {(a) }}$ & $\begin{array}{c}\text { Dead } \\
\text { or Missing } \\
\end{array}$ & $\begin{array}{r}\text { Proportion } \\
\text { Surviving } \\
\end{array}$ & $\begin{array}{c}\text { Mean } \\
\text { Proportion } \\
\text { Surviving } \\
\end{array}$ & $\begin{array}{l}\text { Standard } \\
\text { Deviation }\end{array}$ \\
\hline COMP MT-A & 1 & 15 & 5 & 0.75 & & \\
\hline COMP MT-A & 2 & 18 & 2 & 0.90 & & \\
\hline COMP MT-A & 3 & 18 & 2 & 0.90 & 0.86 & 0.07 \\
\hline COMP MT-A & 4 & 17 & 3 & 0.85 & & \\
\hline COMP MT-A & 5 & 18 & 2 & 0.90 & & \\
\hline COMP MT-B & 1 & 18 & 2 & 0.90 & & \\
\hline COMP MT-B & 2 & 11 & 9 & 0.55 & & \\
\hline COMP MT-B & 3 & 17 & 3 & 0.85 & 0.71 & 0.16 \\
\hline COMP MT-B & 4 & 12 & 8 & 0.60 & & \\
\hline COMP MT-B & 5 & 13 & 7 & 0.65 & & \\
\hline R-MUD & 1 & 20 & 0 & 1.00 & & \\
\hline R-MUD & 2 & 19 & 1 & 0.95 & & \\
\hline R-MUD & 3 & 18 & 2 & 0.90 & 0.94 & 0.07 \\
\hline R-MUD & 4 & 17 & 3 & 0.85 & & \\
\hline R-MUD & 5 & 20 & 0 & 1.00 & & \\
\hline C-AMP & 1 & 18 & 2 & 0.90 & & \\
\hline C-AMP & 2 & 18 & 2 & 0.90 & & \\
\hline C-AMP & 3 & 18 & 2 & 0.90 & 0.88 & 0.04 \\
\hline C-AMP & 4 & 18 & 2 & 0.90 & & \\
\hline C-AMP & 5 & 16 & 4 & 0.80 & & \\
\hline
\end{tabular}

(a) Survival based on initial exposure of 20 organisms per replicate. 
TABLE B.2. Water Quality Summary for A. abdita 10-Day, Static Renewal, Benthic Acute Toxicity Test

\begin{tabular}{|c|c|c|c|c|c|c|c|c|c|c|}
\hline \multirow{2}{*}{$\begin{array}{l}\text { Sediment } \\
\text { Treatment }\end{array}$} & \multicolumn{2}{|c|}{$\begin{array}{c}\text { Temperature } \\
\left({ }^{\circ} \mathrm{C}\right)\end{array}$} & \multicolumn{2}{|c|}{$\mathrm{pH}$} & \multicolumn{2}{|c|}{$\begin{array}{c}\text { Dissolved } \\
\text { Oxygen } \\
(\mathrm{mg} / \mathrm{L})\end{array}$} & \multicolumn{2}{|c|}{$\begin{array}{c}\text { Salinity } \\
(0 / \infty 0)\end{array}$} & \multicolumn{2}{|c|}{$\begin{array}{c}\text { Total } \\
\text { Ammonia }^{(a)} \\
\text { (mg/L) }\end{array}$} \\
\hline & Min & Max & Min & Max & Min & Max & Min & Max & Min & Max \\
\hline \multicolumn{11}{|l|}{ Acceptable } \\
\hline Range & 18.0 & 22.0 & 7.30 & 8.30 & $\geq 4.6$ & $N A^{(b)}$ & 28.0 & 32.0 & NA & 30.0 \\
\hline MT-A & 19.4 & 20.1 & 8.15 & $8.89^{(c)}$ & 6.8 & 8.0 & 30.0 & 31.0 & $<1.00$ & 1.22 \\
\hline MT-B & 19.3 & 20.0 & 8.12 & $8.71^{\text {(c) }}$ & 7.2 & 8.1 & 30.0 & 31.0 & $<1.00$ & 1.00 \\
\hline R-MUD & 19.5 & 20.2 & 7.83 & 8.11 & 7.3 & 8.1 & 30.0 & 30.5 & $<1.00$ & 1.58 \\
\hline C-AMP & 19.5 & 20.1 & 7.82 & 8.11 & 7.3 & 8.4 & 30.0 & 30.5 & $<1.00$ & 1.78 \\
\hline
\end{tabular}

(a) Total ammonia is measured in overlying water.

(b) NA Not applicable.

(c) Data point is outside of acceptable range. 
TABLE B.3. Results of 96-Hour Cadmium Reference Toxicant Test with A. abdita

\begin{tabular}{|c|c|c|c|c|c|c|}
\hline $\begin{array}{c}\text { Cadmium } \\
\text { Concentration } \\
(\mathrm{mg} / \mathrm{L}) \\
\end{array}$ & Replicate & Live $^{(a)}$ & $\begin{array}{c}\text { Dead } \\
\text { or Missing } \\
\end{array}$ & $\begin{array}{c}\text { Proportion } \\
\text { Surviving }\end{array}$ & $\begin{array}{c}\text { Mean } \\
\text { Proportion } \\
\text { Surviving } \\
\end{array}$ & $\begin{array}{l}\text { Standard } \\
\text { Deviation }\end{array}$ \\
\hline 0.00 & 1 & 20 & 0 & 1.00 & & \\
\hline 0.00 & 2 & 18 & 2 & 0.90 & & \\
\hline 0.00 & 3 & 19 & 1 & 0.95 & 0.95 & 0.05 \\
\hline 0.19 & 1 & 16 & 4 & 0.80 & & \\
\hline 0.19 & 2 & 17 & 3 & 0.85 & & \\
\hline 0.19 & 3 & 17 & 3 & 0.85 & 0.83 & 0.03 \\
\hline 0.38 & 1 & 12 & 8 & 0.60 & & \\
\hline 0.38 & 2 & 11 & 9 & 0.55 & & \\
\hline 0.38 & 3 & 15 & 5 & 0.75 & 0.63 & 0.10 \\
\hline 0.75 & 1 & 5 & 15 & 0.25 & & \\
\hline 0.75 & 2 & 8 & 12 & 0.40 & & \\
\hline 0.75 & 3 & 8 & 12 & 0.40 & 0.35 & 0.09 \\
\hline 1.50 & 1 & 0 & 20 & 0.00 & & \\
\hline 1.50 & 2 & 0 & 20 & 0.00 & & \\
\hline 1.50 & 3 & 2 & 18 & 0.10 & 0.03 & 0.06 \\
\hline
\end{tabular}

(a) Survival based on initial exposure of 20 organisms per replicate. 
TABLE B.4. Water Quality Summary for 96-Hour Cadmium Reference Toxicant Test with $A$. abdita

\begin{tabular}{|c|c|c|c|c|c|c|c|c|}
\hline \multirow{2}{*}{$\begin{array}{c}\text { Cadmium } \\
\text { Concentration } \\
(\mathrm{mg} / \mathrm{L})\end{array}$} & \multicolumn{2}{|c|}{$\begin{array}{c}\text { Temperature } \\
{ }^{\circ} \mathrm{C}\end{array}$} & \multicolumn{4}{|c|}{$\begin{array}{c}\text { Dissolved } \\
\text { Oxygen } \\
\text { (mg/L) }\end{array}$} & \multicolumn{2}{|c|}{$\begin{array}{c}\text { Salinity } \\
(\% \circ)\end{array}$} \\
\hline & Min & Max & Min & Max & Min & Max & Min & $\operatorname{Max}$ \\
\hline \multicolumn{9}{|l|}{ Acceptable } \\
\hline Range & 18.0 & 22.0 & 7.30 & 8.30 & 4.6 & $N A^{(a)}$ & 28.0 & 32.0 \\
\hline 0.00 & 19.3 & 20.5 & 7.93 & 8.11 & 6.6 & 7.6 & 30.0 & 30.5 \\
\hline 0.19 & 19.5 & 20.3 & 7.90 & 8.17 & 7.0 & 7.6 & 30.0 & 30.5 \\
\hline 0.38 & 19.3 & 20.3 & 7.85 & 8.14 & 6.7 & 7.5 & 30.5 & 31.0 \\
\hline 0.75 & 19.3 & 20.4 & 7.66 & 8.06 & 6.9 & 7.6 & 30.5 & 31.0 \\
\hline 1.50 & 19.5 & 20.3 & 7.50 & 8.07 & 6.8 & 7.6 & 30.0 & 31.0 \\
\hline
\end{tabular}

(a) NA Not applicable. 


\section{Appendix C}

Bioaccumulation Test Data, MOTBY 
TABLE C.1. Results of 28-Day M. nasuta Bioaccumulation Test

\begin{tabular}{|c|c|c|c|c|c|c|}
\hline $\begin{array}{l}\text { Sediment } \\
\text { Treatment }\end{array}$ & Replicate & $\operatorname{Live}^{(a)}$ & $\begin{array}{l}\text { Dead or } \\
\text { Missing }\end{array}$ & $\begin{array}{c}\text { Proportion } \\
\text { Surviving }\end{array}$ & $\begin{array}{c}\text { Mean } \\
\text { Proportion } \\
\text { Surviving } \\
\end{array}$ & $\begin{array}{l}\text { Standard } \\
\text { Deviation }\end{array}$ \\
\hline MT-A & 1 & 22 & 3 & 0.88 & & \\
\hline MT-A & 2 & 25 & 0 & 1.00 & & \\
\hline MT-A & 3 & 25 & 0 & 1.00 & & \\
\hline MT-A & 4 & 24 & 1 & 0.96 & & \\
\hline MT-A & 5 & 25 & 0 & 1.00 & 0.97 & 0.05 \\
\hline MT-B & 1 & 24 & 1 & 0.96 & & \\
\hline MT-B & 2 & 25 & 0 & 1.00 & & \\
\hline MT-B & 3 & 25 & 0 & 1.00 & & \\
\hline MT-B & 4 & 20 & 5 & 0.80 & & \\
\hline MT-B & 5 & 25 & 0 & 1.00 & 0.95 & 0.09 \\
\hline R-MUD & 1 & 22 & 3 & 0.88 & & \\
\hline R-MUD & 2 & 24 & 1 & 0.96 & & \\
\hline R-MUD & 3 & 24 & 1 & 0.96 & & \\
\hline R-MUD & 4 & 21 & 4 & 0.84 & & \\
\hline R-MUD & 5 & 24 & 1 & 0.96 & 0.92 & 0.06 \\
\hline C-SB & 1 & 23 & 2 & 0.92 & & \\
\hline C-SB & 2 & 22 & 3 & 0.88 & & \\
\hline C-SB & 3 & 24 & 1 & 0.96 & & \\
\hline C-SB & 4 & 23 & 2 & 0.92 & & \\
\hline C-SB & 5 & 25 & 0 & 1.00 & 0.94 & 0.05 \\
\hline
\end{tabular}

(a) Survival based on initial exposure of 25 organisms per replicate. 
TABLE C.2. Water Quality Summary for $M$. nasuta 28-Day Bioaccumulation Test

\begin{tabular}{|c|c|c|c|c|c|c|c|c|}
\hline \multirow{2}{*}{$\begin{array}{l}\text { Sediment } \\
\text { Treatment }\end{array}$} & \multicolumn{2}{|c|}{$\begin{array}{l}\text { Temperature } \\
{ }^{\circ} \mathrm{C}\end{array}$} & \multicolumn{2}{|c|}{$\mathrm{pH}$} & \multicolumn{2}{|c|}{$\begin{array}{c}\text { Dissolved } \\
\text { Oxygen } \\
(\mathrm{mg} / \mathrm{L})\end{array}$} & \multicolumn{2}{|c|}{$\begin{array}{l}\text { Salinity } \\
(0 / 00)\end{array}$} \\
\hline & Min & Max & Min & Max & Min & Max & Min & Max \\
\hline \multicolumn{9}{|l|}{ Acceptable } \\
\hline Range & 12.0 & 16.0 & 7.30 & 8.30 & $\geq 5$ & $N A^{(a)}$ & 28.0 & 32.0 \\
\hline MT-A & 14.4 & 15.8 & 7.62 & 8.06 & 7.1 & 9.2 & 30.0 & 31.0 \\
\hline MT-B & 14.5 & 15.8 & 7.71 & 8.12 & 7.2 & 9.2 & 30.0 & 31.0 \\
\hline R-MUD & 14.4 & 15.6 & 7.71 & 8.14 & 7.0 & 9.3 & 30.0 & 31.5 \\
\hline C-SB & 14.5 & 15.7 & 7.66 & 8.12 & 7.5 & 9.4 & 30.0 & 31.0 \\
\hline
\end{tabular}

(a) NA Not applicable. 
TABLE C.3. Results of $M$. nasuta 96-Hour Copper Reference Toxicant Test

\begin{tabular}{cccc}
$\begin{array}{c}\text { Copper } \\
\text { Concentration } \\
\text { (mg/L) }\end{array}$ & Live ${ }^{(a)}$ & $\begin{array}{c}\text { Dead or } \\
\text { Missing }\end{array}$ & $\begin{array}{c}\text { Proportion } \\
\text { Surviving }\end{array}$ \\
\hline 0 & 10 & 0 & 1.00 \\
0.25 & 9 & 1 & 0.90 \\
0.50 & 8 & 2 & 0.80 \\
0.75 & 10 & 0 & 1.00 \\
1.00 & 6 & 4 & 0.60 \\
1.50 & 7 & 3 & 0.70 \\
2.50 & 5 & 5 & 0.50
\end{tabular}

(a) Survival based on initial exposure of 10 organisms per concentration. 
TABLE C.4. Water Quality Summary for M. nasuta 96-Hour Copper Reference Toxicant Test

\begin{tabular}{|c|c|c|c|c|c|c|c|c|}
\hline \multirow{2}{*}{$\begin{array}{c}\text { Copper } \\
\text { Concentration } \\
(\mathrm{mg} / \mathrm{L})\end{array}$} & \multicolumn{2}{|c|}{$\begin{array}{c}\text { Temperature } \\
\left({ }^{\circ} \mathrm{C}\right) \\
\end{array}$} & \multicolumn{4}{|c|}{$\begin{array}{c}\text { Dissolved } \\
\text { Oxygen } \\
(\mathrm{mg} / \mathrm{L})\end{array}$} & \multicolumn{2}{|c|}{$\begin{array}{c}\text { Salinity } \\
(0 / 00)\end{array}$} \\
\hline & Min. & Max. & Min. & Max. & Min. & Max. & Min. & Max. \\
\hline \multicolumn{9}{|l|}{ Acceptable } \\
\hline Range & 12.0 & 16.0 & 7.30 & 8.30 & $\geq 5$ & $N A^{(a)}$ & 28.0 & 32.0 \\
\hline 0.00 & 14.7 & 15.6 & 7.82 & 8.10 & 7.6 & 8.3 & 30.5 & 30.5 \\
\hline 0.25 & 14.8 & 15.5 & 7.75 & 8.03 & 7.6 & 8.4 & 30.5 & 30.5 \\
\hline 0.50 & 14.8 & 15.6 & 7.77 & 8.02 & 7.6 & 8.4 & 30.5 & 30.5 \\
\hline 0.75 & 14.8 & 15.6 & 7.72 & 8.00 & 7.6 & 8.3 & 30.5 & 30.5 \\
\hline 1.00 & 14.8 & 15.6 & 7.67 & 8.00 & 7.5 & 8.4 & 30.5 & 30.5 \\
\hline 1.50 & 14.8 & 15.6 & 7.48 & 7.97 & 7.4 & 8.3 & 30.5 & 30.5 \\
\hline 2.50 & 14.8 & 15.6 & 7.52 & 7.95 & 7.2 & 8.4 & 30.0 & 30.5 \\
\hline
\end{tabular}

(a) NA Not applicable. 
TABLE C.5. Results of $T$. japonica 28-Day Bioaccumulation Test

\begin{tabular}{|c|c|c|c|c|c|c|}
\hline $\begin{array}{l}\text { Sediment } \\
\text { Treatment }\end{array}$ & Replicate & Live $^{(a)}$ & $\begin{array}{l}\text { Dead or } \\
\text { Missing }\end{array}$ & $\begin{array}{c}\text { Proportion } \\
\text { Surviving } \\
\end{array}$ & $\begin{array}{c}\text { Mean } \\
\text { Proportion } \\
\text { Surviving } \\
\end{array}$ & $\begin{array}{l}\text { Standard } \\
\text { Deviation }\end{array}$ \\
\hline MT-A & 1 & 25 & 0 & 1.00 & & \\
\hline MT-A & 2 & 25 & 0 & 1.00 & & \\
\hline MT-A & 3 & 25 & 0 & 1.00 & & \\
\hline MT-A & 4 & 25 & 0 & 1.00 & & \\
\hline MT-A & 5 & 25 & 0 & 1.00 & 1.00 & 0.00 \\
\hline MT-B & 1 & 25 & 0 & 1.00 & & \\
\hline MT-B & 2 & 25 & 0 & 1.00 & & \\
\hline MT-B & 3 & 25 & 0 & 1.00 & & \\
\hline MT-B & 4 & 25 & 0 & 1.00 & & \\
\hline MT-B & 5 & 25 & 0 & 1.00 & 1.00 & 0.00 \\
\hline R-MUD & 1 & 25 & 0 & 1.00 & & \\
\hline R-MUD & 2 & 25 & 0 & 1.00 & & \\
\hline R-MUD & 3 & 25 & 0 & 1.00 & & \\
\hline R-MUD & 4 & 25 & 0 & 1.00 & & \\
\hline R-MUD & 5 & 25 & 0 & 1.00 & 1.00 & 0.00 \\
\hline C-SB & 1 & 25 & 0 & 1.00 & & \\
\hline C-SB & 2 & 25 & 0 & 1.00 & & \\
\hline C-SB & 3 & 25 & 0 & 1.00 & & \\
\hline C-SB & 4 & 25 & 0 & 1.00 & & \\
\hline C-SB & 5 & 25 & 0 & 1.00 & 1.00 & 0.00 \\
\hline
\end{tabular}

(a) Survival based on initial exposure of 25 organisms per replicate. 
TABLE C.6. Water Quality Summary for T. japonica 28-Day Bioaccumulation Test

\begin{tabular}{|c|c|c|c|c|c|c|c|c|c|c|}
\hline \multirow{2}{*}{$\begin{array}{l}\text { Sediment } \\
\text { Treatment }\end{array}$} & \multicolumn{2}{|c|}{$\begin{array}{l}\text { Temperature } \\
{ }^{\circ} \mathrm{C}\end{array}$} & \multicolumn{2}{|c|}{$\mathrm{pH}$} & & $\begin{array}{l}\text { Ived } \\
\text { jen } \\
\text { /L) }\end{array}$ & & $\begin{array}{l}\text { nity } \\
\text { oo) }\end{array}$ & \multicolumn{2}{|c|}{$\begin{array}{c}\text { Total } \\
\text { Ammonia }^{(a)} \\
(\mathrm{mg} / \mathrm{L})\end{array}$} \\
\hline & Min & Max & Min & Max & Min & Max & Min & Max & Min & Max \\
\hline \multicolumn{11}{|l|}{ Acceptable } \\
\hline Range & 13.0 & 17.0 & 7.30 & 8.30 & $\geq 5$ & $N A^{(b)}$ & 28.0 & 32.0 & $\mathrm{NE}^{(c)}$ & NE \\
\hline MT-A & 14.6 & 15.9 & 7.81 & 8.11 & 7.3 & 9.0 & 30.0 & 31.5 & 3.41 & 3.41 \\
\hline MT-B & 14.5 & 16.1 & 7.79 & 8.10 & 7.4 & 9.1 & 30.0 & 31.5 & 2.50 & 2.50 \\
\hline R-MUD & 14.6 & 16.3 & 7.37 & 8.11 & 7.5 & 8.9 & 30.5 & 31.0 & $<1.0$ & $<1.0$ \\
\hline C-SB & 14.6 & 16.0 & 7.81 & 8.12 & 7.3 & 9.1 & 30.0 & 31.0 & $<1.0$ & $<1.0$ \\
\hline
\end{tabular}

(a) Ammonia measured in overlying water.

(b) NA Not applicable.

(c) NE Not established.

(d) Data point out of range. 
TABLE C.7. Results of T. japonica 96-Hour Copper Reference Toxicant Test

\begin{tabular}{cccc}
$\begin{array}{c}\text { Copper } \\
\begin{array}{c}\text { Concentration } \\
(\mathrm{mg} / \mathrm{L})\end{array}\end{array}$ & Live(a) & $\begin{array}{c}\text { Dead or } \\
\text { Missing }\end{array}$ & $\begin{array}{r}\text { Proportion } \\
\text { Surviving }\end{array}$ \\
\hline 0 & 10 & 0 & 1.00 \\
0.25 & 10 & 0 & 1.00 \\
0.50 & 10 & 0 & 1.00 \\
0.75 & 10 & 0 & 1.00 \\
1.00 & 10 & 0 & 1.00 \\
1.50 & 10 & 0 & 1.00 \\
2.50 & 10 & 0 & 1.00 \\
\hline
\end{tabular}

(a) Survival based on initial exposure of 10 organisms for each concentration. 
Table C.8. Water Quality Summary for T. japonica 96-Hour, Copper Reference Toxicant Test

\begin{tabular}{ccccccccc}
$\begin{array}{c}\text { Copper } \\
\begin{array}{c}\text { Concentration } \\
(\mathrm{mg} / \mathrm{L})\end{array}\end{array}$ & \multicolumn{2}{c}{$\begin{array}{c}\text { Temperature } \\
\left({ }^{\circ} \mathrm{C}\right)\end{array}$} & \multicolumn{2}{c}{$\mathrm{pH}$} & \multicolumn{2}{c}{$\begin{array}{c}\text { Dissolved } \\
\text { Oxygen } \\
(\mathrm{mg} / \mathrm{L})\end{array}$} & \multicolumn{2}{c}{$\begin{array}{c}\text { Salinity } \\
\text { (o/oo) }\end{array}$} \\
\cline { 2 - 9 } & Min. & Max. & Min. & Max. & Min. & Max. & Min. & Max. \\
\hline $\begin{array}{c}\text { Acceptable } \\
\text { Range }\end{array}$ & 13.0 & 17.0 & 7.30 & 8.30 & 5.0 & $\mathrm{NA}^{\text {(a) }}$ & 28.0 & 32.0 \\
0.00 & 14.7 & 15.9 & 7.66 & 8.09 & 7.5 & 8.7 & 30.5 & 30.5 \\
0.25 & 14.7 & 15.7 & 7.91 & 8.05 & 7.6 & 8.9 & 30.5 & 30.5 \\
0.50 & 14.8 & 15.7 & 7.85 & 8.02 & 7.6 & 8.8 & 30.5 & 30.5 \\
0.75 & 14.8 & 15.9 & 7.78 & 8.02 & 7.6 & 8.7 & 30.5 & 30.5 \\
1.00 & 14.8 & 15.7 & 7.81 & 8.03 & 5.3 & 8.8 & 30.5 & 30.5 \\
1.50 & 14.7 & 15.7 & 7.51 & 8.01 & 7.2 & 8.5 & 30.5 & 30.5 \\
2.50 & 14.7 & 15.8 & 7.56 & 8.02 & 7.5 & 8.5 & 30.5 & 30.5 \\
\hline
\end{tabular}

(a) NA Not applicable. 